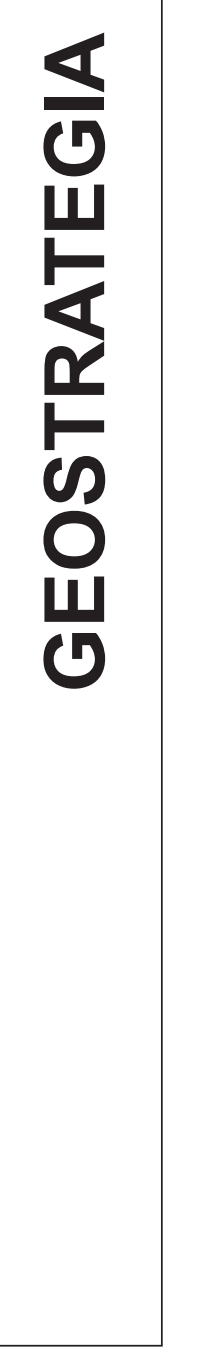





\section{Andrzej SAKSON}

Instytut Zachodni, Poznań

Uniwersytet im. Adama Mickiewicza, Poznań

\section{GEOSTRATEGICZNE ASPEKTY „PROBLEMU KALININGRADZKIEGO”}

Rozpad ZSRR, trudności polityczne związane z kształtowaniem się nowego państwa rosyjskiego i pogłębiający się kryzys w Rosji zrodziły liczne projekty dalszej przebudowy geopolitycznej Obwodu Kaliningradzkiego. W rosyjskiej prasie zaczęto omawiać kolejne propozycje, dotyczące zwiększenia samodzielności gospodarczej, przyznania autonomii i zmiany statusu Obwodu, co miałoby zapewnić jego szybki rozwój.

Proponowano m.in. przesiedlić do Obwodu Niemców rosyjskich i przekształcić go w Bałtycką Republikę Niemiecką w składzie Rosji. Realizacja tego pomysłu niosła jednak zagrożenie możliwością przyłączenia Obwodu do Niemiec.

Pojawiły się również koncepcje wprost zakładające oddzielenie Obwodu od Rosji:

- przekazanie Obwodu Polsce i (lub) Litwie;

- zwrot Obwodu Niemcom;

- odtworzenie Prus Wschodnich (już suwerennych) na byłych ziemiach pruskich, wchodzących teraz w skład Rosji, Polski i Litwy;

- ustalenie w Obwodzie kondominium - pozostającego pod wspólnymi rządami różnych podmiotów (wśród nich wymieniano Unię Europejską, Rosję, Niemcy, Polskę, Litwę, Szwecję);

- przekształcenie regionu w czwarte niezależne państwo nadbałtyckie (obok Litwy, Łotwy, Estonii).

Wszystkie wyżej wymienione koncepcje obiecywały szybki rozwój regionu i podwyższenie poziomu życia jego mieszkańców. Tymczasem izolacja Obwodu od Rosji pociągnęłaby za sobą krach jego gospodarki, opierającej się na dostawach taniego paliwa i energii, wielu rodzajów surowców z innych regionów kraju, obsługiwaniu rosyjskich stosunków w handlu zagranicznym, dostawach na rynek całej Rosji większości produkcji. Jednak najistotniejsze jest to, że Obwód stanowi część rosyjskiej przestrzeni kulturowej i edukacyjnej, z której wyodrębnienie się oznaczałoby zniszczenie systemów edukacji, nauki i kultury regionu. To znaczy, że politycznie izolowany od pozostałego terytorium Rosji Obwód Kaliningradzki nieuchronnie przekształciłby się w podupadły obszar, a standard życia mieszkańców nieuchronnie musiałby się obniżyć.

Jedynym celem wyżej wymienionych koncepcji było - zdaniem badaczy rosyjskich - doprowadzenie do ,izolacji i w końcu oddzielenia Obwodu Kaliningradzkiego od Rosji'. Co prawda, na szczeblu oficjalnym nigdy nie poruszano tych spraw i nie przeprowadzano żadnych negocjacji na temat zmiany statusu Obwodu. Dopiero pod koniec lat dziewięćdziesiątych, kiedy Rosja zaczęła przezwyciężać kryzys gospodarczy i sta- 
bilizować się politycznie, postulaty o potrzebie izolacji Obwodu zaczęto propagować mniej natarczywie ${ }^{1}$.

W przeciwieństwie do wyżej wymienionych koncepcji, miejscowi naukowcy razem z moskiewskimi i petersburskimi ekspertami zaczęli opracowywać realne plany dotyczące rozwoju Obwodu w warunkach enklawy, jako regionu współpracy Federacji Rosyjskiej i UE, oraz wzmacniania jego roli w gospodarce Rosji. Rząd państwa podjął działania, które miały rekompensować dodatkowe koszty z powodu droższego tranzytu. Wśród nich wymienić należy zwłaszcza ustawę o ustanowieniu Specjalnej Strefy Ekonomicznej w Obwodzie Kaliningradzkim, a także Federalny Program Docelowy „Rozwój Obwodu Kaliningradzkiego do 2010 r.” oraz przyjęta w 2011 r. strategia rozwoju regionu na 25 lat. Uwzględniając je, opracowuje się i realizuje realną strategię socjalno-ekonomicznego rozwoju regionu ${ }^{2}$.

Wzrostowi zainteresowania przeszłością regionu towarzyszyły próby zrozumienia jego związków z teraźniejszością, oceniania własnego stosunku do tego terenu, który teraz zamieszkuje ludność Rosji, ale gdzie pozostały ślady mieszkającej kiedyś tutaj ludności niemieckiej i (w znacznie mniejszym stopniu) pruskiej. Zwłaszcza trudne to było dla młodzieży, która urodziła się tutaj i nie miała żadnych wspomnień o „,wielkiej” Rosji, ale nie mogła również na terenie Obwodu Kaliningradzkiego odnaleźć własnych „korzeni historycznych”. Na przykład niektórzy uczniowie i absolwenci szkół zawodowych na początku pieriestrojki stworzyli organizacje „Bawaria” i „Prusy”, propagujące idee oddzielenia Obwodu Kaliningradzkiego od ZSRR, domagające się wolności i demokracji, likwidacji zapóźnień w rozwoju w stosunku do państw rozwiniętych ${ }^{3}$.

Mieszkańcy Obwodu odczuwają skutki izolacji od pozostałej części kraju. Nawet czas jest tutaj odmienny niż w innych regionach Rosji: w marcu 1989 r. wprowadzono nowy sposób obliczania czasu (godzinna różnica w stosunku do czasu moskiewskiego). Duże znaczenie ma również wpływ kultur sąsiadów - polskiej, litewskiej i istniejącej tutaj w ciągu stuleci niemieckiej, i to, że mieszkańcy Obwodu pochodzą nie tylko z różnych regionów Rosji, ale i z innych republik byłego ZSRR.

Jednak różnica w porównaniu z pozostałą częścią kraju nie jest aż tak wielka, żeby mówić o kształtowaniu się w Obwodzie Kaliningradzkim szczególnej kultury, odmiennej od rosyjskiej.

Zdaniem rosyjskich badaczy i polityków „Nie wolno mówić o mieszkańcach Obwodu jak o szczególnym narodzie, który różni się od narodu rosyjskiego. Te różnice mają charakter regionalny, etnograficzny, czyli są to różnice w ramach jednej kultury rosyjskiej. Mieszkańcy Kaliningradu nie tylko rozmawiają w tym samym języku z mieszkańcami innych obwodów i regionów rosyjskich, lecz przyswajają w rodzinie i szkole takie same elementy kultury, normy moralne, zasady zachowania, jak i mieszkańcy Nowogrodu, Smoleńska, Tweru i Kurska, Petersburga oraz Moskwy. To pozwala

1 Szerzej: http:// www.kaliningrad.ru (10.05.2005).

2 Por. A. P. Klemieszew, S. D. Kozłow, G. M. Fiedorow, Ostrow sotrudniczestwa, Kaliningrad 2002; W. W. Iwczenko, Nauczno-techniczeskij potiencyat osobnoj ekonomiczeskoj zony Rossii / Kaliningrad, Kaliningrad 1998; S. Korgopołow, A. Goradiłow, A. Kulikow, A. Gomin, XXI wiek: Osobnaja Zona i Osobnyj Status, Kaliningrad 2001.

3 Szerzej: http://www.kaliningrad.ru (1.02.2005). 
im przeciwstawiać się zewnętrznym wpływom innych kultur (co nie wyłącza zapożyczeń niektórych ich elementów). Podobnie też i sąsiedzi-obcokrajowcy podczas wzajemnych kontaktów doznają wpływu rosyjskiego"4.

Wyjątkowość Obwodu Kaliningradzkiego w stosunku do innych regionów Rosji polega na jego eksklawowym położeniu oraz na tym, iż od 1 maja 2004 roku jest on „wyspą w Unii Europejskiej”. Powoduje to, że politycy z Moskwy oraz Kaliningradu regularnie składają zapewnienia o jego trwałej przynależności państwowej do Rosjí. Kwestia ta uzyskała specjalną nazwę ,problem kaliningradzki” (kaliningradskaja problema) ${ }^{6}$.

Zdaniem moskiewskiego eksperta Grigorija Banatiana, wokół „kaliningradzkiego precedensu” zbyt długo toczyła się dyskusja „,czym jest Kaliningrad dla Rosji. Wojskową forpoczta, czy jak obecnie stwierdzono, ważnym narodowym projektem i pilotażowym obszarem współpracy z UE? Z tego względu brak jest jeszcze założeń

4 Ibidem.

5 I tak np. w maju 2004 roku przewodniczący Dumy obwodowej Władimir Nikitin po raz kolejny zapewnił, iż: „Poza Rosją przyszłości Obwodu Kaliningradzkiego nie widzę, i nikt z polityków regionalnych tematu niezależności najbardziej zachodniego obszaru Rosji nie rozważa". Według słów Nikitina, na tym terytorium obowiązkowo będzie musiał istnieć inny system ekonomiczny niż w pozostałej części Rosji. „System z góry jest przesądzony położeniem geograficznym Obwodu Kaliningradzkiego, a jakość i poziom życia kaliningradczyków stopniowo będzie zbliżać się do europejskiego, wyprzedzając wskaźniki rosyjskie”. Patrz: „Obwód Kaliningradzki. Przegląd faktów, wydarzeń, opinii” (dalej: „OK”) 2004, nr 5, s. 3. W kwietniu 2006 roku Siergiej Mironow, przewodniczący Rady Federacji, urzędujący w Moskwie, stwierdził, że: ,[...] polityka państwowa Rosji w stosunku do Obwodu Kaliningradzkiego tradycyjnie opiera się na dwóch fundamentalnych zasadach. Pierwsza - jednolitość terytorialna, podmiotem której jest wasz Obwód. A druga - uznanie specjalnego statusu tego unikalnego, najbardziej zachodniego regionu kraju. W praktyce oznacza to, z jednej strony, konsekwentną obronę praw mieszkańców Obwodu Kliningradzkiego tak samo, jak i innych obywateli rosyjskich, stworzenie normalnego trybu przemieszczania się przez terytoria ościenne Polski i Litwy. Z drugiej strony - utworzenie na terytorium Obwodu Kaliningradzkiego Specjalnej Strefy Ekonomicznej, na podstawie ustawy, która weszła w życie 1 kwietnia 2006 roku. Podczas jej akceptacji członkowie Rady Federacji kierowali się tym, że tryb specjalny, związany także z ulgami celnymi i podatkowymi, zapewni niezbędne warunki do dynamicznego rozwoju społeczno-gospodarczego jednego z kluczowych regionów Rosji”. Patrz: „OK” 2006, nr 4, s. 10. Szef Sztabu Generalnego Sił Zbrojnych Federacji Rosyjskiej gen. Jurij Bałujewskij w październiku 2005 roku stwierdził, że obecność rosyjskich sił zbrojnych w obwodzie to „symbol suwerenności Rosji na tym terytorium, które faktycznie zamknięte jest między państwami NATO”. Bałujewskij zauważył także, że są pewne siły, które chciałyby powrotu Kaliningradu «w inne ramki». Ale to jest nasza ziemia, zroszona została ona krwią naszych ojców i dziadków. I o tę ziemię będziemy walczyć sposobem gospodarczym, politycznym, a jeżeli trzeba, to i wojskowym”. Stwierdził także, że: „W Obwodzie Kaliningradzkim, tym nowym oknie Rosji do Europy, skupione są nie tylko interesy państw - przy czym nie tylko Europy, ale i świata w ogóle”. „OK” 2005, nr 10, s. 29. Gieorgij Boos, odpowiadając w kwietniu 2006 r. na pytanie o misję, którą powierzył mu prezydent Putin, mianując go gubernatorem Obwodu Kaliningradzkiego, zauważył, że główne zadanie, jakie wyznaczył mu prezydent, to: „wyćwiczyć na przykładzie Obwodu integrację z Europą”. Według niego ,integracja po linii Unii Europejskiej wydaje się być całkiem możliwa. Łatwo wyobrazić sobie Obwód Kaliningradzki jako część przestrzeni europejskiej, z bezwizowym wyjazdem, swobodną migracją i swobodną wymianą towarów. Na bardziej skomplikowaną wygląda sytuacja $\mathrm{z}$ integracją po linii NATO. Tu na razie nie ma jeszcze rozeznania, jak będą układać się stosunki”. „OK” 2006, nr 4, s. 41.

${ }^{6}$ Por. ,Kaliningradskaja problema” $w$ zerkale obszczestwiennogo mnienija, Kaliningrad/Moskwa 2002. 
polityki federalnej. [...] Od Obwodu Kaliningradzkiego centrum nigdy nie odstąi"”.7. Według opinii wielu kaliningradzkich ekspertów „,pilotażowość” Obwodu wobec Unii Europejskiej to rzecz już nieaktualna od kilku lat. Jest ona pochodną złych stosunków pomiędzy Rosją a UE. Jak zauważył w maju 2007 r. Fiodor Lukcjanow, redaktor naczelny czasopisma „Rossija”, w polityce globalnej: „My nie mamy dzisiaj żadnego modelu relacji z UE, tak więc «pilotować» nie ma czego" ". Dla mieszkańców Obwodu ważna jest kwestia systemu wizowego po przystapieniu Polski i Litwy w 2008 roku do układu z Schengen.

Redakcja „Kaliningradskoj Prawdy” w komentarzu odredakcyjnym opublikowanym 18 maja 2007 roku stwierdziła, iż: „Większość mieszkańców regionu już nawet nie marzy o tym, by jeździć z Rosji do Rosji jak kiedyś, swobodnie. Na odwrót, uważa się za rzecz zupełnie normalną posiadać jako dodatek do dowodu osobistego jeszcze i paszport zagraniczny. Do którego, naturalnie, trzeba wklejać wizy. I jeżeli trzeba będzie za nie płacić - to będziemy płacić. Nigdzie nie uciekniemy, wokół, jak w rezerwacie, druty kolczaste i słupy graniczne, bez wiz nie wyjedziesz. Być może, taki jest ten nasz «pilotażowy» los"9.

Obwód znalazł się w sytuacji „podwójnej peryferii” w sensie gospodarczym i społecznym. Po pierwsze został odcięty od zasadniczego terytorium Rosji wysokimi taryfami tranzytowymi i przeszkodami wynikającymi z wprowadzenia w krajach sąsiednich norm wewnętrznych UE, np. rygorystyczne przepisy weterynaryjne czy ekologiczne. Po drugie, izolowany jest od terytorialnie bliskiej Europy Zachodniej różnego rodzaju barierami, w tym także wizowymi. Od 1 czerwca 2007 r. uległ zmianie tryb uzyskiwania przez mieszkańców regionu wiz polskich i litewskich - długoterminowe dokumenty, upoważniające do wielokrotnych wyjazdów do „najbliższej zagranicy", będą dostępne dla nielicznych. Zasadniczo Kaliningradczycy będą mogli otrzymać wizy jednokrotne na okres do trzech miesięcy, przy czym tylko odpłatnie - po 35 euro.

Taki stan rzeczy wpływa oczywiście na wyobrażenia mieszkańców o przyszłości regionu, w którym żyją. Na zadane w 2002 roku pytanie: „Która z powyższych wersji dotyczących losu Obwodu Kaliningradzkiego wydaje się Wam najlepsza z Waszego punktu widzenia", uzyskano następujące wyniki:

- Obwód pozostanie w składzie Rosji, ale jego status będzie się różnił od statusu innych rosyjskich regionów $-38 \%$;

- Obwód pozostanie w składzie Rosji i będzie mieć taki sam status jak inne rosyjskie regiony $-21 \%$;

- Obwód będzie istniał w obrębie Rosji, ale faktycznie będzie żył zgodnie ze swoimi prawami $-19 \%$;

G. Banatian, Żditie czto skażet Putin. Moskiewskij ekspiert-ekonomist sczitajet, czto kaliningradskaja obłast'stoit na porogie bolszych pieriemien, „Kaliningradskaja Prawda”, 22.11.2005, s. 1, 2.

8 „OK” 2007, nr 5, s. 70, 71.

9 Ibidem. Krytyczne opinie na temat polityki centrum wobec Obwodu formułowane są od dhuższego czasu. Np. Aleksandr Riabuszew na łamach tygodnika „Majak Bałtiki” w październiku 2003 roku pisał o „kolonialnym stosunku Moskwy do problemów Obwodu, a ich polityczne zagadywanie może przybrać dla Rosji na jej najdalszym zachodzie zły obrót i przerodzić się w wybuch społeczny, co w ostatecznym rachunku skutkować może utratą regionu”. Por.: „OK” 2003, nr 10, s. 4. 
- Obwód przestanie być częścią Rosji i stanie się samodzielnym państwem - 5\%;

- Obwód przestanie być częścią Rosji i stanie się częścią innego państwa - 3\%.

Z powyższych danych wynika, iż aż $65 \%$ badanych opowiada się za innym niż dotychczas statusem Obwodu, jedynie jedna piąta respondentów uważa obecną sytuację za odpowiednią (11\% nie miało zdania w tej sprawie $)^{10}$.

Badania porównawcze na podobny temat przeprowadzono w latach 2001-2005 ${ }^{11}$. Wynika z nich, iż w 2005 r. 44,4\% mieszkańców Obwodu widziałoby swój region jako obszar Federacji Rosyjskiej, ale posiadający prawa specjalnej strefy ekonomicznej. Ogółem, bo aż 65,8\% respondentów było niezadowolonych z istniejącego stanu rzeczy (jest to identyczny odsetek osób jak w powyżej przedstawionych badaniach z 2002 r.). Jedynie co piąty mieszkaniec regionu (19,2\%) uważał, iż nie jest konieczna zmiana statusu Obwodu (co dziesiąty - 10,2\%, oczekiwał, że na bazie Obwodu powstanie niepodległe państwo, a 9,8\% opowiadało się za republiką w składzie Federacji Rosyjskiej). Dynamikę zmian wyobrażeń na temat przyszłości ukazuje tabela 1.

Tabela 1

Poglądy na temat przyszlego statusu Obwodu Kaliningradzkiego w latach 2001-2005

(w \%)

\begin{tabular}{|c|c|c|c|c|}
\hline Oczekiwany status Obwodu w przyszłości & 2001 & 2003 & 2004 & 2005 \\
\hline Niezawisłe państwo & 11,1 & 10,8 & 7,2 & 10,2 \\
\hline $\begin{array}{l}\text { Terytorium o takich samych uprawnieniach jak w Federacji Rosyj- } \\
\text { skiej i Unii Europejskiej }\end{array}$ & 14,5 & 19,8 & 6,2 & 8,0 \\
\hline Republika w składzie Rosji & 15,8 & 14,3 & 7,6 & 9,8 \\
\hline $\begin{array}{l}\text { Obwód w składzie Federacji Rosyjskiej z prawami odrębnej strefy } \\
\text { gospodarczej }\end{array}$ & 39,3 & 34,4 & 46,6 & 44,4 \\
\hline Obwód w składzie Federacji Rosyjskiej & 10,3 & 14,1 & 29,8 & 19,2 \\
\hline Region w składzie innego państwa & \multirow{2}{*}{8,4} & \multirow{2}{*}{6,6} & \multirow{2}{*}{2,6} & 3,6 \\
\hline Inne wyobrażenia, brak odpowiedzi & & & & 4,8 \\
\hline
\end{tabular}

Źródło: Region stotrudniczestwa, Wypusk 3(46): Problema sieparatizma w usłowijach anklawnych tierritorij, red. A. Klemieszew, Kaliningrad 2005, s. 35.

Najwięcej zwolenników istniejącego stanu rzeczy jest na wsi (22,3\%), a najmniej w małych miastach (14\%). Największe zróżnicowania postaw wobec przyszłości regionu, ze względu na miejsce zamieszkania, występuje w przypadku oceny „republika w składzie FR" - aż 16,7\% mieszkańców małych miast opowiada się za takim rozwiązaniem wobec jedynie 5,7\% mieszkańców Kaliningradu. W przypadku pozostałych wariantów odpowiedzi różnice są nieznaczne.

Inaczej rozkładają się wyniki, jeśli uwzględnia się wiek respondentów: 14,2\% osób w wieku 19-29 lat opowiadało się za niepodległym państwem, podczas gdy chciało tego tylko 4,3\% osób powyżej 50. roku życia. Odwrotne proporcje wystąpiły w ocenie

10 „Kaliningradskaja problema” $w$ zierkale..., op. cit.

11 Region sotrudniczestwa, Wypusk 3(46): Problema sieparatizma w usłowijach anklawnych tierritorij, red. A. Klemieszew, Kaliningrad 2005. 
zachowania istniejącego stanu rzeczy. Za jego utrzymaniem opowiadało się 43,7\% osób w wieku powyżej 60 lat, 7,8\% w wieku od 30 do 39 lat oraz 10,9\% najmłodszych respondentów (19-29 lat). Im młodszy wiek badanych tym więcej wskazań za odrębną republiką w składzie Federacji Rosyjskiej (13,1\% 19-29-latków wobec 4,2\% osób powyżej 69 lat). Dawni i nowi mieszkańcy w podobny sposób postrzegali przyszłość Obwodu (wyraźne różnice występują w ocenie przyszłości regionu w składzie innego państwa (chciało tego 10,8\% migrantów przybyłych po 1991 roku wobec 2,5\% osób tutaj urodzonych lub długo tu mieszkających).

Wśród mieszkańców Obwodu silne obawy budziła możliwość wysunięcia roszczeń terytorialnych przez inne państwa. O takich pretensjach ze strony Niemiec przekonanych było aż 63,8\% badanych (zdecydowanie tak - 36,0\%, bardziej tak niż nie - 27,8\%). Jedynie co dziesiąty mieszkaniec Obwodu (9,4\%) uważał, że Niemcy nie będą rościć takich pretensji. 43,4\% badanych (zdecydowanie tak - 20,6\%, bardziej tak niż nie - 22,8\%) było przekonanych, że takie pretensje skieruje Litwa. O rzekomych pretensjach płynących ze strony Polski przeświadczonych było 34,6\% badanych (zdecydowanie tak - 15,6\%, bardziej tak niż nie - 19,0\%). Im młodszy wiek badanych tym przekonanie o wysuwaniu roszczeń terytorialnych było mniejsze. Np. 43,7\% osób w wieku powyżej 60 lat zdecydowanie obawia się Niemiec, wobec 31,2\% osób w wieku 30-39 lat ${ }^{12}$.

W zakresie badań porównawczych przeprowadzonych w latach 1993-2002 na temat stacjonujących w Obwodzie wojsk zarysowała się w przeciagu dziesięciu lat istotna zmiana postaw. Zdecydowanie wzrosło oczekiwanie zwiększenia liczby stacjonujących wojsk (o 19\%) oraz zachowania istniejącego potencjału wojskowego (o 24\%). Jednocześnie drastycznie zmalała (o 33\%) liczba osób opowiadających się za zmniejszeniem liczby wojsk oraz za ich wyprowadzeniem (do 1\%). Kwestie te ilustruje tabela 2 .

Tabela 2

Stosunek mieszkańców Obwodu Kaliningradzkiego do tamtejszego potencjału wojskowego w latach 1993-2002 (w \%)

\begin{tabular}{||l|c|c|c|c|c||}
\hline \multicolumn{1}{|c|}{ Warianty odpowiedzi } & $\mathbf{1 9 9 3}$ & $\mathbf{1 9 9 4}$ & $\mathbf{1 9 9 6}$ & $\mathbf{2 0 0 0}$ & $\mathbf{2 0 0 2}$ \\
\hline Konieczność zwiększania liczebności wojska i uzbrojenia & - & - & 13 & 18 & 19 \\
\hline $\begin{array}{l}\text { Zachowanie liczby wojska i uzbrojenia na dotychczasowym } \\
\text { poziomie }\end{array}$ & 32 & 55 & 70 & 62 & 56 \\
\hline $\begin{array}{l}\text { Konieczność zmniejszenia liczebności wojska i uzbrojenia } \\
\text { w Obwodzie }\end{array}$ & 41 & 24 & 13 & 10 & 8 \\
\hline Konieczność wyprowadzenia wojsk i uzbrojenia z Obwodu & 20 & 16 & 1 & 2 & 1 \\
\hline Brak odpowiedzi & 7 & 5 & 3 & 9 & 16 \\
\hline
\end{tabular}

Źródło: ,, Kaliningradskaja problema” w zierkale obszczestwiennogo mnienija, Kaliningrad/Moskwa 2002, s. 8.

W lutym 2007 roku przeprowadzono w obwodzie badania na temat stosunku do Unii Europejskiej. Mieszkańców regionu zapytano czy Obwód Kaliningradzki powi-

12 Ibidem, s. 45-59. 
nien stać się częścią Unii Europejskiej. 8,5\% respondentów odpowiedziało twierdząco na pytanie socjologów. Prawie połowa badanych $(46,3 \%)$ wybrała odpowiedź „Obwód powinien stać się częścią Unii Europejskiej, pozostając terytorium rosyjskim”. Nieco mniej - 41,6\%, wskazało wariant „,powinien pozostać tylko częścią Rosji”,13.

$\mathrm{Z}$ ogółu powyżej prezentowanych wyników badań wysnuć można wnioski, iż ponad połowa mieszkańców (około 60\%) opowiada się za zmianą istniejącego statusu Obwodu. Świadczy to o „rozchwianiu” świadomości. W przeciwieństwie do osób żyjących w Polsce oraz na Litwie, dla mieszkańców Obwodu Kaliningradzkiego kwestia zmiany statusu prawnego i częściowo także terytorialnego jest problemem realnie istniejącym, wpływającym na ogólne samopoczucie i tożsamość.

Postawy te podtrzymywane są przez różnego rodzaju informacje docierające do mieszkańców regionu głównie z Niemiec i Litwy. W wielu formach przez rozmaite siły społeczne i polityczne oraz z różną intensywnością formułowane są w tych krajach różnego rodzaju pretensje i uwagi, które często negują istniejącą przynależność państwową oraz status Obwodu. Pomimo iż ,retoryka rewindykacyjna” płynie głównie z sąsiedniej Litwy, to jednak największe obawy formułowane są pod adresem Niemiec. Wynika to w znacznej mierze $\mathrm{z}$ faktu, iż do niedawna jeszcze ziemie te przynależały do Prus i Niemiec. Nie bez znaczenia jest również współczesna pozycja polityczna i gospodarcza obu tych państw. Litwa z uwagi na ograniczony potencjał ludnościowy, terytorialny, gospodarczy i militarny oraz fakt, iż przyłączenie Wileńszczyzny oraz Kraju Kłajpedzkiego „zawdzięcza” Związkowi Radzieckiemu, postrzegana jest w Kaliningradzie i Moskwie z jednej strony z nieskrywaną irytacją, ale także z drugiej jako słabszy partner, którego bardziej lub mniej można lekceważyć. Widoczne to stało się szczególnie od czasu przejęcia władzy przez W. Putina w 2000 roku.

Napięcia między Rosją a Litwą, Polską i Zachodem mają swoją dynamikę. Emancypacja „odrodzonej Rosji” jest bowiem nową ideologią władz rosyjskich, która zastapiła hasła walki z komunizmem z czasów Borysa Jelcyna czy przezwyciężania „pojelcynowskiego chaosu” w pierwszych latach prezydentury W. Putina. Pomimo iż rosyjski PKB kształtuje się na poziomie zbliżonym do włoskiego, to Rosja wciąż jest ważnym graczem globalnym o ambicjach imperialnych, której nie sposób izolować lub ignorować.

Władze w Moskwie i Kaliningradzie, podobnie jak i opinia publiczna w regionie, z dużą wrażliwością reagują nie tylko na różnego rodzaju przejawy gospodarczej aktywności niemieckiej w Obwodzie (np. inwestycyjna), ale także noszącej charakter „rewanżystowski”. Kaliningradzki publicysta W. Smirnow w rozmowie z konsulem generalnym Niemiec w Kaliningradzie w sierpniu 2006 roku zauważył m.in. iż: „Jest opinia, jakoby biznes niemiecki znakomicie znał potencjał ekonomiczny Kaliningradu, jednak rząd Niemiec powstrzymuje jego dążenie do inwestowania w region, żeby tym samym dystansować się od ewentualnych oskarżeń o to, jakoby RFN «wykupywała» obwód rosyjski..."14.

13 „OK” 2007, nr 2, s. 33, 34

14 „OK” 2006, nr 8, s. 33. Konsul Generalny RFN w Kaliningradzie Guido Herz, komentując głosy prasy rosyjskiej na temat wspierania przez władze w Berlinie planu nowych przesiedleń Niemców rosyjskich, 22 sierpnia 2006 r. zauważył, że: „Rząd federalny Niemiec absolutnie niczego wspól- 
Z dużym oburzeniem wśród polityków i dziennikarzy rosyjskich - tak w Moskwie, jak i w Kaliningradzie - spotkało się tzw. małe zapytanie, skierowane do rządu federalnego Niemiec w październiku 2004 roku przez 71 deputowanych Bundestagu z opozycyjnej podówczas CDU/CSU. Jego inicjatorami byli Jürgen Klimke i Erwin Marschewski. Zapytanie podnosiło aż 50 kwestii dotyczących sytuacji Obwodu Kaliningradzkiego po rozszerzeniu Unii Europejskiej na Wschód.

Na łamach „Niezawisimoj Gaziety” 15 października 2004 roku ukazał się artykuł pod znamiennym tytułem Niemiecki Reichstag gotów jest do zwrotu „Obwodu Kaliningradzkiego". Oto obszerniejszy fragment tego artykułu, który ukazuje rosyjski sposób myślenia i argumentacji w tej sprawie: „Szef niemieckiego MSZ Joschka Fischer i jego podwładni w tych dniach usilnie pracuja nad odpowiedzią na zapytanie opozycji w sprawie sytuacji w Kaliningradzie. Od drugiej osoby w rządzie RFN parlamentarzyści domagają się zgody na utworzenie litewsko-rosyjsko-polskiego regionu, który odpowiadałby historycznemu obszarowi Prus Wschodnich. To jest zaledwie jedno z ponad 50 pytań postawionych rządowi przez grupę złożoną z 71 deputowanych $\mathrm{CDU} / \mathrm{CSU}$. Jak poinformował «NG» jeden z inicjatorów tej akcji deputowany Juergen Klimke, liczy on na uzyskanie odpowiedzi rządowej do końca października.

W swoim zapytaniu parlamentarzyści, dwukrotnie wymieniając «Obwód Kaliningradzki», określają ten region rosyjski kilkadziesiąt razy jako «Obwód Köningsberski» - przy czym bez żadnych cudzysłowów. Organizatorzy bundestagowskiej interpelacji twierdza, że kieruje nimi troska o przyszłość «Obwodu Königsberskiego, zaliczanego do problemowych regionów peryferii UE». Jednak obserwatorzy uważają, że w tej akcji prześwieca ukryte tło.

Wspomniany deputowany J. Klimke specjalizuje się w swojej frakcji w problematyce dotyczącej turystyki. Ten temat podnoszony jest także w interpelacji, ale w całkiem osobliwym ujęciu: co myśli rząd federalny o możliwości «wspólnego turystycznego zagospodarowania przez Polskę, Litwę i Rosję historycznego terytorium Prus Wschodnich»? Jednocześnie opracowujący interpelację z niedwuznacznym podtekstem interesują się «jak dalece ekstensywne wojskowe wykorzystanie Obwodu Königsberskiego stanowi przeszkodę» dla rozwoju jego gospodarki? Innymi słowami - czy nie lepiej usunąc stamtąd rosyjską obecność wojskową?

Inny inicjator interpelacji, Erwin Marschewski, politycznie jest wyraźniejszy. We frakcji chrześcijańskich demokratów stoi on na czele grupy roboczej «wypędzonych i uciekinierów». Oczywiście wśród tych, którzy podpisali zapytanie, znalazła się przywódczyni «Związku Wypędzonych» Erika Steinbach, wywołująca swoimi skandalicznymi przemówieniami szczególne oburzenie w Polsce. Nic dziwnego, że niektóre sformułowania kryją w sobie «ideę» wytyczenia na nowo mapy regionalnej.

Pytanie 14 brzmi: «Jak rząd federalny odnosi się do pomysłu utworzenia litewsko-rosyjsko-polskiego euroregionu, który geograficznie odpowiadałby historyczne-

nego nie ma z inicjatywą rosyjsko-niemieckiej kompanii Rusformstroj Wosroschdenie GmbH, która oświadczyła o wcieleniu w życie w RFN specjalnego programu na rzecz powrotu do Rosji Niemców rosyjskich. Chciałbym dodać, że ze strony rządu Niemiec nigdy nie było podobnego programu w zakresie przesiedlenia Niemców rosyjskich, naturalnie, w przyszłości tego też nie będzie. Jest to w całej pełni program prywatny" - podkreślił dyplomata. Ibidem, s. 34. 
mu obszarowi Prus Wschodnich?» Przy tym nie precyzuje się czy powinien to być jakiś wydzielony z odpowiednich państw twór, czy coś innego. Kierunek został jednak zaznaczony. W pytaniu nr 15 autorzy zapytania wyjaśniają już stosunek rządu «do propozycji nazwania tego regionu 'Prussia' (Prusy)». Oczywiście, inicjatorzy wiedzą, że liczenie na powszechną naiwność jest lekkomyślnością. Erwin Marschewski ujawnił na stronie internetowej (Rusland-aktuel), że «małym zapytaniem» chcąjedynie pobudzić rząd do bardziej aktywnego udziału w życiu regionu. «W każdym razie nie jestem rewanżystą» - podkreślił, wspominając o obowiązku przestrzegania umów powojennych. Z kolei Jürgen Klimke traktuje zapytania o charakterze prowokacyjnym za w pełni usprawiedliwiony środek do osiagnięcia celu, a mianowicie - uzyskania «jasnej informacji ze strony rządu federalnego». Cała reszta, jak przyznaje sam Klimke, «naturalnie, to są brednie»"15.

Niemieckie władze zdystansowały się wobec tych kwestii w specjalnej odpowiedzi. Usatysfakcjonowały one Rosję. W listopadzie 2004 roku Departament Informacji i Wydawnictw MSZ Federacji Rosyjskiej wydał specjalny komentarz w związku z zapytaniem rosyjskich środków masowego przekazu odnośnie do odpowiedzi rządu RFN na interpelację frakcji CDU/CSU nt. „Przyszłość gospodarcza Obwodu Königsberskiego po rozszerzeniu Unii Europejskiej”. Czytamy w nim m.in., iż: „Treść odpowiedzi Rządu RFN na tę dosyć drażliwą interpelację deputowanych frakcji CDU/CSU w Bundestagu wywołuje nasze zadowolenie. Utrzymana w taktownych sformułowaniach, w istocie odrzuca ona próby autorów interpelacji ignorowania historycznych realiów międzynarodowo-prawnych i ostatecznych powojennych uregulowań w Europie. Rząd RFN faktycznie zdystansował się, w szczególności, od «nieznanych mu idei» utworzenia na bazie Obwodu Kaliningradzkiego jakiegoś tworu europejskiego «Prussia» w granicach geograficznych byłych Prus Wschodnich lub wydzielenia Obwodu z prawnej i celnej przestrzeni Rosji. W odpowiedzi znajduje potwierdzenie przywiązania kierownictwa Niemiec do współdziałania z Rosją w kwestii kaliningradzkej w ogólnym kontekście współpracy rosyjsko-niemieckiej"16.

Z nieskrywaną irytacją w Kaliningradzie przyjmowane były wystąpienia przedstawicieli Ziomkostwa Prus Wschodnich, którzy do niedawna jeszcze zapraszani byli na różnego rodzaju uroczystości związane np. z obchodami rocznic powstania miast. W trakcie takich wystapień padały słowa krytyki i pouczenia pod adresem Rosjan, którzy nie potrafią się „odpowiednio gospodarzyć” i doprowadzili „region do ruiny”.17.

Problematyka Prus Wschodnich oraz Obwodu Kaliningradzkiego jest przedmiotem zainteresowania nie tylko niemieckich ziomkostw, ale także licznych środowisk naukowych i społecznych ${ }^{18}$.

15 „OK” 2004, nr 10, s. 58, 59

16 „OK” 2004, nr 11, s. 47.

17 Szerzej: http://www.kaliningrad.ru (10.05.2003).

18 Od wielu lat Ostsee-Akademie, a później Baltische-Akademie z Lubeki była organizatorem wielu spotkań i seminariów poświęconych tej problematyce. Jednym z nich było spotkanie naukowców dotyczące Obwodu Kaliningradzkiego, zorganizowane w dniach 22-23 czerwca 2006 roku przez Europa-Universität , Viadrina” we Frankfurcie nad Odrą. Związane było ono z realizacją dwuletniego projektu badawczego pn. „Przemiany krajobrazów pamięci w postsocjalistycznej przestrzeni”. W trakcie spotkania wygłoszono m.in. referaty nt. losów kościołów w Obwodzie po 1945 r. czy też zawartości archiwów o Köngsbergu i Prusach Wschodnich. 
Obwód Kaliningradzki to dla Litwy i Polski obszar istotny z geopolitycznego punktu widzenia. Dla Litwy to także ważny partner gospodarczy (np. Litwa zaspokaja $80 \%$ zapotrzebowania Obwodu na energię elektryczną, wiele przedsiębiorstw litewskich prowadzi tu działalność). W pierwszych latach po rozpadzie ZSRR i odzyskaniu niepodległości przez Litwę relacje między tymi państwami koncentrowały się wokół trzech głównych problemów:

- obecności wojskowej Rosji w Obwodzie Kaliningradzkim;

- ustalenia przebiegu granicy, jej przepustowości oraz przyjęcia zasad jej przekraczania przez osoby i towary oraz członków sił zbrojnych i sprzętu wojskowego;

- ustanowienia równoprawnych i korzystnych dla obu stron stosunków gospodar$\operatorname{czych}^{19}$.

Najbardziej złożony okazał się problem związany z ustanowieniem granicy państwowej suwerennej Litwy z Rosją oraz „kaliningradzki problem wizowy”. Ta ostatnia kwestia aktualna jest do dnia dzisiejszego.

Po wieloletnich kontrowersjach i spotkaniach dwustronnych komisji doszło w 1997 roku do podpisania umowy granicznej przez prezydentów obu państw: Algirdasa Brazauskasa i Borysa Jelcyna. Litewski Sejm ratyfikował ją dwa lata później, ale rosyjska Duma zwlekała z ratyfikacją z powodów politycznych. Rosyjscy politycy obawiali się, że gdy zatwierdzą umowę, zostaną zlikwidowane ostatnie bariery na drodze Litwy do NATO, a tym samym państwo to ostatecznie wypadnie z orbity wpływów rosyjskich.

W czerwcu 2002 roku frakcje centrowe i lewicowe rosyjskiej Dumy państwowej przygotowały projekt uchwały anulującej tajne protokoły do paktu Ribbentrop-Mołotow. Oznaczałoby to powrót do przedwojennych granic, a zatem powrót Wilna do Polski oraz „zwrot Kłajpedczyzny”. Rosyjscy deputowani chcieli w ten sposób poróżnić Polskę i Litwę, a na tę ostatnią wywrzeć presję, by skłonić ją do ustępstw w sprawie rosyjskich korytarzy do Kaliningradu.

Intryga zainicjowana przez deputowanego Wiktora Ałksnisa, nazywanego „czarnym pułkownikiem", opierała się na następującym założeniu: wypowiedzenie paktu Ribbentrop-Mołotow będzie automatycznie oznaczać podważenie państwowej przynależności Wileńszczyzny, która do 1939 roku była częścią Drugiej Rzeczpospolitej. Deputowany Ałksnis powiedział przed kamerami telewizji, że jeśli teraz Moskwa podważy porząadek graniczny powstały po II wojnie światowej, to Litwa znajdzie się w trudnej sytuacji i będzie bardziej skłonna do ustępstw wobec rosyjskich żądań. Wniosku tego nie poparli zwolennicy W. Putina i stał się on przez to bezprzedmioto$\mathrm{wy}^{20}$. Nacjonalistom wtórowały jednak media rosyjskie, które twierdziły, że do czasu, aż Duma nie ratyfikuje umowy, Rosja jest w stanie podważyć integralność terytorialną Litwy. Litwini odrzucali te głosy z oburzeniem, przypominając, że jej jedność terytorialną Rosja uznała już w 1991 r. w umowie o współpracy i dobrosąsiedzkich stosunkach.

19 E. Wojnowski, Obwód Kaliningradzki Federacji Rosyjskiej - od obszaru zamkniętego ku regionowi wspótpracy (1946-2006), Olsztyn 2006, s. 113.

${ }^{20}$ S. Popowski, Jak sktócić Polskę z Litwq. Deputowani proponuja unieważnić pakt Ribbentrop-Mołotow, ,Rzeczpospolita”, 19.06.2002, s. A 6. 
Ostatecznie osiagnięto kompromis, w wyniku którego w maju 2003 roku Duma zatwierdziła stosowny traktat ${ }^{21}$. W zamian za uznanie granicy Rosjanie z Kaliningradu będą mogli jeździć w uproszczony sposób do pozostałej części państwa przez należącą do Unii Litwę ${ }^{22}$. W sprawę tę zaangażowana była Unia Europejska, która w wydatny sposób przyczyniła się do rozwiązania tego sporu $^{23}$. W istocie nie chodziło tu o spór o granice. Rosja nie miała pretensji terytorialnych wobec Litwy. Gorące debaty graniczne były elementem sporu o warunki tranzytu do i z Kaliningradu.

Pomimo ratyfikacji litewsko-rosyjskiego traktatu granicznego, nadal w Rosji podnosiły się głosy domagające się zmiany tego stanu rzeczy. Domagano się m.in. budowy specjalnego korytarza przez terytorium Litwy i Polski. W październiku 2004 roku Władimir Żyrinowski, wiceprzewodniczący Dumy Państwowej Federacji Rosyjskiej i lider Liberalno-Demokratycznej Partii Rosji zaproponował przekopanie tunelu podziemnego do Obwodu Kaliningradzkiego. Uzasadnił to tym, że od Nowego Roku mieszkańcy eksklawy będą mogli jeździć do pozostałej części Rosji tylko na podstawie paszportu zagranicznego. Tunel o długości $90 \mathrm{~km}$ mógłby, według Żyrinowskiego, przebiegać pod terytorium neutralnym między granicą polsko-litewską. Jego zdaniem Litwa powinna się na to zgodzić, gdyż „możemy zaproponować zwrot Kłajpedy pod jurysdykcję Niemiec i wówczas Litwa utraci swój ostatni port”. „Mamy możliwość oddziaływania na Litwę poprzez wywóz odpadów z Ignalińskiej Elektrowni Atomowej

${ }^{21}$ W trakcie ożywionej debaty parlamentarnej padały różne,,argumenty” historyczne. Deputowany komunistyczny Nikołaj Bindiukow twierdził, iż trzecia część terytoriów znajdujących się w obrębie tych granic Litwy, które Duma ma zatwierdzić, to ziemie, które Wilno „dostało od ZSRR”. Deputowany wyjaśnił, że chodzi przede wszystkim o Kłajpedę i „, terytoria białoruskie”, czyli tereny, które między wojnami należały do Polski. Konstantin Kosaczow z proputinowskiej Ojczyzny-Całej Rosji przypomniał, że z Litwą Rosja ma stosunki lepsze niż z dwoma pozostałymi krajami bałtyckimi, i dodał, że między Wilnem a Moskwą nie ma sporów terytorialnych. Za ratyfikacją układu granicznego głosowało 268 deputowanych (wymagane minimum - 226 głosów), przeciw - 138, jeden się wstrzymał.

22 W wyniku obustronnych uzgodnień ustalono, iż do momentu wejścia Litwy do strefy Schengen obowiązywać będą następujące zasady tranzytu przez terytorium Litwy: 1) mieszkańcy Obwodu Kaliningradzkiego mogą przekraczać granicę Litwy na podstawie swoich dowodów osobistych i przebywać na jej terytorium do trzydziestu dni bez wiz; 2) przejazd tranzytowy z Obwodu do Rosji odbywać się będzie w trybie bezwizowym; 3) specjalne przepisy regulować będą transport wojskowy. Patrz.: E. Wojnowski, Obwód..., op. cit., s. 113. Osiagnięty kompromis wywołał niezadowolenie w Rosji. I tak np. we wrześniu 2003 roku około 20 członków Partii Narodowo-Bolszewickiej zabarykadowało się i przykuło kajdankami w jednym z wagonów pociągu Moskwa-Kaliningrad. Zażądali od władz Litwy natychmiastowego i całkowitego zniesienia wiz tranzytowych dla obywateli rosyjskich. „Nie dopuścimy do tego, aby Kaliningrad został odcięty od Rosji” - stwierdzili. Wszystko to rozgrywało się na litewskiej stacji kolejowej Kiena. Na pomoc ściągnięto oddział litewskiego specnazu. Po półtorej godzinie wszyscy „limonowcy” zostali aresztowani. Rosyjski MSZ potępił ich wyskok. Patrz: „Rzeczpospolita”, 15.09.2003, s. A 8.

${ }^{23}$ Por.: I. Pawlicki, Na razie wizy bez wiz. Bruksela o Kaliningradzie, „Gazeta Wyborcza”, 19.09.2002, s. 3; K. Kurczab-Redlich, Z Rosji do Rosji. Mieszkańcy Kaliningradu będa jeździć w zamkniętych wagonach?, „Polityka” 2002, nr 26, s. 36-38. Z Kaliningradu do centralnej Rosji prowadzą dwa główne szlaki kolejowe: Kaliningrad-Kybartai-Kowno-Wilno-Psków (z odgałęzieniami do Moskwy i St. Petersburga) oraz Kaliningrad-Wilno-Mińsk-Smoleńsk-Moskwa. Trzy główne połączenia drogowe to: Kaliningrad-Kowno-Psków, Kaliningrad-Ryga-Psków oraz Kaliningrad-Suwałki-Mińsk-Smoleńsk-Moskwa. Istnieje także połączenie promowe na trasie Kaliningrad-St. Petersburg. 
- dodał. - Mamy wiele dźwigni nacisku". Skądinąd wiadomo, że budowa jednego kilometra moskiewskiego metra kosztuje od 40 do $80 \mathrm{mln}$ dolarów ${ }^{24}$. Ten sam polityk podczas pobytu w Kaliningradzie 28 lutego 2006 roku wystapił z propozycją wymiany terenów między Rosją i Litwą w celu utworzenia wspólnej przestrzeni rosyjskiej z Obwodem Kaliningradzkim. Oświadczył także, iż „W perspektywie kierownictwo państwa powinno rozwiązać sprawę styku Obwodu Kaliningradzkiego z Rosją". Twierdził, że najlepiej to uczynić, ,osiagając zgodę na wymianę terenów na odcinku litewsko-polskim. Tam zaledwie $90 \mathrm{~km}$, jakiś pasek ziemi z Litwą można wymienić, żeby możliwa stała się wreszcie normalna komunikacja mieszkańców Kaliningradu z pozostałą częścią Rosji”"25.

10 września Sejm Republiki Litewskiej uchwalił rezolucję, w której uznał, że utworzenie „korytarza” dla tranzytu ludzi i ładunków między Obwodem Kaliningradzkim i pozostałą częścią Rosji jest sprzeczne z interesami Litwy. Zgodnie z tym dokumentem, parlament „kategorycznie odrzuca jakiekolwiek wysiłki” na rzecz utworzenia korytarza tranzytowego. Projekt rezolucji zgłosił przewodniczący Sejmu Arturas Paulauskas. Jak wskazano w dokumencie, Sejm Litwy „nie akceptuje wniesionego w maju 2003 roku przez Rosję do Unii Europejskiej memorandum, które proponuje urzeczywistnienie tranzytu kaliningradzkiego «zgodnie $\mathrm{z}$ wewnętrznym prawem Rosji» i uznania go za wewnętrzny tranzyt Rosji”26.

Komisja litewsko-rosyjska ds. demarkacji granicy rosyjsko-litewskiej powołana została w 2004 roku. Jej pierwsze posiedzenie połączone z wyjazdem nad granicę odbyło się wiosną 2005 roku w Wilnie, a kolejne w lutym 2006 roku w Kaliningradzie $^{27}$.

O drażliwości stosunków litewsko-rosyjskich świadczą reakcje w Kaliningradzie na litewskie propozycje dotyczące teraźniejszości i przyszłości Obwodu. 11 maja 2006 roku w St. Petersburgu, z inicjatywy konsulatu Litwy w tym mieście, odbyło się spotkanie z Reimundasem Łopata, dyrektorem Instytutu Stosunków Międzynarodowych i Nauk Politycznych Uniwersytetu Wileńskiego. Poświęcone było ono promocji jego książki pt. Anatomia zaktadnika... Dossier Jubileuszu Kaliningradzkiego. Autor analizuje w niej procesy geopolityczne i ekonomiczne zachodzące w Obwodzie Kaliningradzkim. Główna teza pracy sprowadza się do stwierdzenia, że Kaliningrad stał się zakładnikiem w wielkiej grze Rosji i Unii Europejskiej, a w Kaliningradzie o wszystkim decyduje Moskwa. Na prezentacji swojej książki A. Łopata oświadczył, że: „Eksklawowość Kaliningradu jest historyczna. Ten region nie po raz pierwszy oddzielony jest od metropolii i już kończyło się to tragedią dla Polski i Litwy. Wszak metropolia zawsze dąży do przyłączenia do siebie eksklawy, a to może stać się tylko wraz z przyłączeniem terytoriów sąsiednich”. Zauważył także, że „Kaliningrad stanowi poważne zagrożenie dla Litwy i Polski” oraz, że „kierownictwo Litwy i Polski rozumie to, a także zdaje sobie sprawę z tego, że spokojnie te kraje będą mogły się czuć tylko wtedy, gdy eksklawa historyczna będzie znajdować się jeżeli nie w składzie, to pod

\footnotetext{
24 „OK” 2004, nr 11, s. 60.

25 „OK” 2006, nr 3, s. 51.

26 "OK” 2004, nr 9, s. 67.

27 „OK” 2006, nr 2, s. 63.
} 
wpływem Litwy i Polski”. Oświadczył także, że Kaliningrad może zostać oderwany od Rosji tylko za zgodą tej ostatniej, ,jeśli dostrzeże ona w tym korzyść w wielkiej grze politycznej" 28 .

Komentując wypowiedzi politologa litewskiego, gubernator Gieorgij Boos oświadczył, że „Kaliningrad wchodzi w skład Rosji, która, jak i każde inne państwo, ma doktrynę obronną. Doktryna przewiduje całkowite bezpieczeństwo i jednolitość kraju, ale nie przewiduje działań ofensywnych". Gubernator oświadczył także, że wypowiedzi R. Łopaty o tym, że Obwód Kaliningradzki przedstawia zagrożenie dla Litwy i Polski, nosi charakter prowokacyjny. Prócz tego zaproponował utworzenie stref zdemilitaryzowanych w Europie Wschodniej. Przypomniał o utworzeniu pierwszej strefy zdemilitaryzowanej w Europie na Wyspach Alandzkich na podstawie umowy pokojowej zawartej w Paryżu w 1856 r. i wysunął sugestię, że ten model nadaje się obecnie do zastosowania celem obrony interesów rosyjskich nad Bałtykiem. Postawił także w jednym rzędzie Obwód Kaliningradzki z czterema Wyspami Kurylskimi, do których zgłasza pretensje Japonia. Oświadczył ponadto, że dokonanie chociażby tylko jednej zmiany terytorialnej granic Rosji pociągnie za sobą mnóstwo następnych: ,Jakiekolwiek nowe podziały terytorialne dzisiaj, za wyjątkiem demarkacyjnych, tam gdzie nie ma granicy, mogą doprowadzić do trzeciej wojny światowej" ${ }^{29}$.

$\mathrm{Z}$ równie ostrą reakcją w Kalinigradzie spotkał się artykuł V. Landsbergisa, deputowanego do Parlamentu Europejskiego, który na łamach pisma "Mažosios Lietuvos” z 13 sierpnia 2007 roku wysunął po raz kolejny pretensje terytorialne pod adresem Obwodu. Autor stoi w nim na stanowisku, iż: „Niezbędne jest światowe porozumienie Rosji, Litwy i Polski z Niemcami w sprawie Köngsberga, przy współudziale Wielkiej Brytanii i USA". Zalicza on Obwód do Małej Litwy, jako że od wieków w Prusach Wschodnich żyli „Litwini-autochtoni”. W artykule posługuje się litewską nazwą miasta: Karalaučius oraz oskarża Rosjan o „genocyd”, wyniszczenie miejscowej ludności w czasie II wojny światowej ${ }^{30}$.

Ten sposób myślenia nie jest niczym nowym wśród litewskich konserwatystów i narodowców. Np. w 2000 roku ukazał się oprotestowany w Rosji, Polsce i na Białorusi Kalendarz Litwina 2000 (2000 lietuvo kalendorius), starannie wydana zielona książeczka w twardej oprawie. Na drugiej stronie kalendarza - mapa Wielkiego Księstwa Litewskiego z okresu największego rozkwitu, „od morza do morza”, oraz portret wielkiego księcia Witolda. W środku m.in. mapa zasięgu występowania Bałtów w XIII wieku, czyli - jak można rozumieć - przodków współczesnych Litwinów (może i Łotyszy?): od Wisły na zachodzie (Prusowie) po Bug na południu (Jaćwingowie), dzisiejszy Mińsk białoruski na wschodzie i współczesne granice Estonii na północy. I wreszcie, na samym końcu książeczki mapa, która wzbudziła najwięcej emocji - Litwa wraz z terenami sąsiadujących państw. Na południe i wschód od litewskich granic,

28 „OK” 2006, nr 5, s. 44-46.

29 Ibidem.

${ }^{30}$ W odpowiedzi na te zarzuty komentator „Kaliningradskoj Prawdy” pisał, iż Litwini przejęli w 1945 roku Kraj Kłajpedzki w wyniku takiego samego ,genocydu” jak Rosjanie Obwód Kaliningradzki. Kraj Kłajpedzki zasiedlono nowymi osadnikami z Litwy, jako że „pruskich Litwinów” było bardzo mało. Patrz: http://www.kaliningradka.ru (27.08.2007). 
przez Suwałki po stronie polskiej i Lidę po białoruskiej, ciaggnie się napis: „Tymczasowo okupowane etniczne ziemie litewskie" ${ }^{\text {31 }}$.

Na tle sporów historycznych, na początku XXI w. pojawiły się także kontrowersje wokół wspomnianych już „korytarzy komunikacyjnych”,32 czy też przerw w dostawie ropy naftowej do zakupionej przez polskie przedsiębiorstwo „Orlen” rafinerii w Możejkach ${ }^{33}$. Dotyczą one również budowy gazociągu bałtyckiego łączącego Rosję z Niemcami ${ }^{34}$.

Pozytywnym sygnałem zmiany we wzajemnych relacjach było powołanie w 2006 roku Wspólnej Rosyjsko-Litewskiej Komisji Historyków. Komisja ta ma rozstrzygnąć najtrudniejsze problemy związane z interpretacją historii stosunków litewsko-rosyjskich ${ }^{35}$.

Stosunki z Polska, na tle relacji Obwodu Kaliningradzkiego z Niemcami i z Litwa, nie wpływają w znaczący sposób na kształtowanie się opinii mieszkańców regionu w sprawie jego przyszłości. Na tradycyjnie dobrze układającą się współpracę regionalną kładzie się cieniem nie najlepszy stan stosunków polsko-rosyjskich. Jeżeli przyjąć, że kontakty władz Kaliningradu z jego zagranicznymi sąsiadami są zależne od moskiewskiego centrum, wówczas trudno się dziwić, iż od początku XXI wieku zostały one znacznie ograniczone i zatraciły swoją dotychczasową dynamikę. Stało się to szczególnie widoczne po zaangażowaniu Polski w ukraińską ,,pomarańczową” rewolucję z listopada 2004 roku $^{36}$. Nie bez znaczenia jest tu krytyka ze strony Polski budowy

31 P. Kościński, Litwa od Suwałk po Lide, „Rzeczpospolita”, 28.01.2000, s. A8.

32 Por.: R. Malik, Jeszcze raz korytarz, ,Rzeczpospolita”, 13.05.2002, s. A2; J. Pawlicki, Korytarzograd, „Gazeta Wyborcza”, 29-30.05.2002, s. 9; S. Popowski, But Rogozina i korytarz, „Rzeczpospolita”, 11.06.2002, s. A2; A. Z. Kamiński, Powrót korytarzowy, „Rzeczpospolita”, 28.06.2002, s. A8; oraz Rosjanie sie obudzili. Sprawa , korytarzy" do Kaliningradu. Wywiad z Gediminasem Kirklisem, szefem komitetu spraw zagranicznych litewskiego parlamentu, „Gazeta Wyborcza”, 1.07.2002, s. 11.

33 I. Komar, W. Radziwinowicz, Wilno-Moskwa: Remont za remont. Rosjanie karza Litwinów za sprzedanie rafinerii Polakom, a Wilno grozi Moskwie remontem szlaku kolejowego do Kaliningradu, „Gazeta Wyborcza”, 22.08.2006, s. 9. Por. także: „OK” 2006, nr 9, s. 54-55; „OK”2007, nr 5, s. 65.

34 Szerzej: http://www.westrus.ru (14.05.2007).

35 „OK” 2006, nr 2, s. 63.

36 W kontekście zaangażowania Polski w wydarzenia na Ukrainie w „Kaliningradzkiej Prawdzie” z 7.12.2004 ukazała się opinia Siergieja Markowa, dyrektora Instytutu Badań Politycznych w Moskwie, który stwierdził, iż ,,pojawiły się obawy odnośnie do przyszłości naszego regionu”. Jego interpretacja wydarzeń jest następująca: „Zgodnie z pewnym planem (wśród którego autorów jest Zbigniew Brzeziński, jeden z ideologów "zimnej wojny») Ameryka, jakoby nie będąc zainteresowana współpracą ze Starą Europa, stawia na nowych członków Unii Europejskiej, szczególnie na Polskę. W wyniku tego jest możliwe odrodzenie Rzeczypospolitej ze zmianą granic Ukrainy (przekaże ona Polsce swoją część zachodnia) i Litwy (ta zwróci Kraj Wileński). Zapewne nie jest przypadkiem udział prezydentów Polski i Litwy A. Kwaśniewskiego i V. Adamkusa w charakterze pośredników na rozmowach w Kijowie". Jego zdaniem w przypadku wzrostu wpływów Polski Obwód Kaliningradzki ryzykuje znalezienie się w zależności od niej. „Wydawałoby się, że historycznie bardziej uzasadnione jest rozpatrywanie w takim kontekście Niemiec. Ale ja mówię właśnie o Polsce - jakiekolwiek niemieckie inicjatywy będą nosić otwarcie rewanżystowski charakter, co jednoznacznie spowoduje ostrą reakcją negatywna. W związku z tym Polska jest bardziej neutralna i, powiedziałbym, dogodna. Dysponując poparciem ze strony USA, może ona na tyle wzmocnić swoją pozycję, że jej kooperacja z Obwodem Kaliningradzkim przerodzi się w coś większego”. Według Siergieja Markowa to „coś większego” naprawdę może doprowadzić do „pomarańczowej” rewolucji. „Jeżeli w waszym regionie nasilą się i bez tego niemałe nastroje prozachodnie, to Obwód całkiem może ogłosić swoje 
gazociągu bałtyckiego czy też spór o dostawy polskiego mięsa do Rosji, w które zaangażowała się Unia Europejska. Ta ostatnia kwestia doprowadziła w dużym stopniu do znacznego ograniczenia dialogu Rosja-Unia Europejska.

Wzmocnienie władz centralnych widoczne jest w Rosji i Obwodzie Kaliningradzkim już od pewnego czasu. Obecnie niemal całkowicie podporządkowana jest im polityka wewnętrzna i gospodarka. O ile prowadzenie rosyjskiego projektu modernizacyjnego leży w interesie Europy, o tyle powrót do imperialnej polityki zagranicznej i ledwie maskowanego autorytaryzmu w sprawach wewnętrznych już nie. Zdaniem Joschki Fischera, w latach 1998-2005 szefa niemieckiego MSZ i przywódcy „Zielonych”: „Większość Rosjan ma orientację zachodnią. W ciaggu najbliższych lat ze strony Rosji pojawi się zarówno możliwość współpracy, jak i ryzyko ingerowania w sprawy wewnątrzeuropejskie" ${ }^{37}$.

W relacjach polsko-kaliningradzkich sprawy historyczne czy też pretensje terytorialne nie mają znaczenia ${ }^{38}$. Od długiego czasu polscy politycy oraz poszczególne siły społeczne nie kwestionują istniejącego statusu i terytorialnego kształtu obwodu ${ }^{39}$. Nie oznacza to jednak, iż relacje te wolne są od problemów. Nadal nie jest rozwiązana kwestia swobodnej żeglugi po Zalewie Wiślanym/Kaliningradzkim i przez Cieśninę Pilawską. Nowym elementem w tym konflikcie stała się zgłoszona w 2006 r. przez polskie władze gotowość przekopania kanału przez Mierzeję Wiślaną, w najwęższym jej miejscu, we wsi Stokrotki. Kanał ten miałby połączyć elbląski port z Bałtykiem, omijając rosyjskie wody terytorialne. Inwestycja ta ma podtekst polityczny ${ }^{40}$. Jedyna

oddzielenie od Rosji i przejście pod jurysdykcję Unii Europejskiej. A UE już wymyśli, co z wami zrobić" - zauważył politolog.

37 J. Fischer, Rosja wraca do imperialnej polityki, „Gazeta Wyborcza”, 5.09.2007, s. 13.

38 Mało znany jest fakt, iż podczas wizyty Nikity Chruszczowa w $1964 \mathrm{r}$. w ośrodku rządowym w Łańsku na Mazurach złożył on propozycję przekazania Obwodu Kaliningradzkiego Polsce w zamian za Dolny Śląsk, który Polska miałaby przekazać zjednoczonym i zneutralizowanym Niemcom. Por. list Gerarda Labudy z 4 maja 2007 roku do autora pracy. Por. także: A. Werblan, Ewolucja stanowiska Władysława Gomutki w sprawie polityki wschodniej Republiki Federalnej Niemiec, w: Recepcja Ostpolitik w RFN $i$ w krajach bloku komunistycznego. Polska, ZSRR, NRD, Czechostowacja, Węgry, red. J. Fiszer, J. Holzer, Warszawa 2004, s. 78, 79.

39 W ostatnim okresie pośród znaczących ugrupowań politycznych jedynie Liga Polskich Rodzin zaprezentowała w 2002 roku odrębne od polskich władz poglądy wobec Obwodu Kaliningradzkiego. Domagała się ona: ,uregulowania statusu rejonu Królewca, który historycznie, geograficznie i geopolitycznie jest częścią polskiego dziedzictwa, w ramach tej regulacji domagamy się wprost natychmiastowej regulacji baz wojskowych, których obecność, w tym stacjonowanie broni atomowej, zagraża bezpieczeństwu Polski”. Oświadczenie wygłoszone 10 stycznia 2002 roku przez posła A. S. Stryjskiego w czasie 10. posiedzenia Sejmu. Cyt. za: „Głos” 2002, nr 3, s. 3. O wcześniejszych polskich głosach „rewizjonistycznych”: A. Sakson, Teraźniejszość i przyszłość Obwodu Kaliningradzkiego. Aspekty polityczne i kwestie bezpieczeństwa europejskiego, „Przegląd Zachodni” 1993, nr 3, s. 49-67.

40 Zgodnie z projektem kanał liczyłby 1,3 km długości, $40 \mathrm{~m}$ szerokości i $5 \mathrm{~m}$ głębokości. Brzegi kanału połączyć ma most stały lub zwodzony. Dzięki temu do Elblagga będą mogły wpływać większe barki. Przekopanie kanału będzie kosztować $60-80$ mln euro ( $85 \%$ tej inwestycji ma pokryć UE). Zgodnie z planami w 2010 r. nowym kanałem przepływałyby pierwsze statki. Od strony Zalewu ma powstać śluza o długości $180 \mathrm{~m}$ i szerokości 24 m, która pozwoliłaby kontrolować przepływ wody i panować nad sytuacją w razie sztormu. Średni czas przepływu kanałem przewiduje się na około 20 minut. Patrz: D. Wilczak, Leczenie kanatowe. Polska-Rosja, „Newsweek”, 27.08.2006, s. 32-34. Por. także: M. Sandecki, Przekopiemy się na Battyk przez Mierzeję Wiślanq?, „Gazeta Wyborcza”, 
droga z Zalewu Wiślanego na Bałtyk prowadzi przez kontrolowaną przez Rosję Cieśninę Pilawską. Rosjanie w maju 2006 roku wstrzymali ruch na zalewie. Utrzymują, że umowa, na podstawie której polskie statki mogły korzystać z ich wód terytorialnych w rejonie Kaliningradu, jest już nieważna, gdyż podpisywali ją jeszcze za rządów J. Stalina w 1946 roku z bratnim państwem socjalistycznym. Teraz Polska jest w UE i braterstwo nie wchodzi w grę.

Po raz pierwszy Rosjanie zabronili pływać polskim jednostkom przez cieśninę w 2003 roku. Upierali się, że pasażerowie udający się na kilkugodzinną wycieczkę do Kalininigradu, nawet jeśli nie schodzą na ląd, powinni mieć wizy. Polski MSZ stanął na stanowisku, że to absurd. Negocjacje z Rosjanami trwały trzy tygodnie i ruch został przywrócony. Sytuacja powtórzyła się w czerwcu 2004 roku. Wtedy Rosjanie po raz pierwszy stwierdzili, że umowa wygasła, ale - jak zaproponowali - są gotowi do ustępstw. Identyczna sytuacja powtórzyła się pod koniec 2005 roku.

Na blokadzie tracą polscy armatorzy, szczególnie Żegluga Gdańska, która zarabiała na wycieczkowych rejsach z Elblaga i Gdańska do Kaliningradu. Na skraju bankructwa stoi wybudowany niedawno za pieniądze UE port w Elblągu, który egzystował dzięki handlowi z Obwodem Kaliningradzkim. 1 września 2009 roku podczas pobytu w Gdańsku z okazji 70-tej rocznicy wybuchu II wojny światowej premier Rosji W. Putin zadeklarował odblokowanie dostępu do Bałtyku i podpisał stosowną umowę w tej sprawie $^{41}$. W sierpniu 2010 roku strona rosyjska zapowiedziała odblokowanie Cieśniny Pilawskiej dla polskich statków ${ }^{42}$.

Kolejną sprawą sporną w relacjach polsko-rosyjskich, a związaną z Obwodem Kaliningradzkim, była wspomniana już koncepcja przeprowadzenia przez terytorium Polski korytarza tranzytowego z Białorusi do obwodu. Pojawiła się ona już w 1993 roku, kiedy to Rosjanie zaproponowali budowę specjalnego korytarza komunikacyjnego omijającego Litwę, z wykorzystaniem trasy samochodowej Grodno-Suwałki-Gołdap-Gusiew ${ }^{43}$. Rosjanie, przy wsparciu Białorusinów, forsowali te plany w latach 1994-1996. Wywołały one w Polsce gwałtowne reakcje polityków oraz ożywioną debatę w mediach. Strona polska stanowczo odmówiła wprowadzenia jakiegokolwiek specjalnego trybu tranzytu czy budowy jakichkolwiek korytarzy przez swoje terytorium. Byłby to potencjalny element konfliktu pomiędzy Polską, Rosją, Białorusią i Litwą ${ }^{44}$. Strona rosyjska przystąpiła do modernizacji drogi na granicy z Białorusia,

8.08.2006, s. 4; tenże, Zalew Wiślany zamknięty na kłódkę, „Gazeta Wyborcza”, 6.07.2007, s. 3. Zdaniem ekspertów Rosjanie zdejmą blokadę, kiedy Polacy przystapią do przekopu Zalewu Wiślanego.

${ }^{41}$ Por.: „Gazeta Wyborcza”, 2.09.2005, s. 4. Ze wstępnych planów pobytu W. Putina w Polsce wynikało, że złoży on wizytę w Braniewie na cmentarzu żołnierzy Armii Czerwonej, którzy polegli w czasie II wojny światowej w Prusach Wschodnich. Wizyta ta jednak nie doszła do skutku.

${ }_{42}$ Por.: M. Sandecki, Blokada zniesiona. Elblag znów z dostępem do morza, „Gazeta Wyborcza”, 23.07.2010, s. 5; Rosja. Po Zalewie Wiślanym bez ograniczeń?, „Gazeta Olsztyńska”, 24-25.07.2010, s. 10; P. Preis, W. Radziwinowicz, Zalew Wiślany stoi otworem. Już nie dzieli, ale łaczy, „Gazeta Wyborcza", 22.07.2010, s. 3.

${ }^{43}$ W. T. Modzelewski, Obwód Kaliningradzki FR na tle stosunków polsko-rosyjskich. Wybrane kwestie sporne, „Przegląd Politologiczny” 2005, nr 4, s. 84, 85.

44 Idea budowy „korytarza suwalskiego" nie jest do zaakceptowania przez Polskę już chociażby z powodu negatywnych doświadczeń historycznych związanych z „korytarzem pomorskim”, który zgodnie z żądaniami A. Hitlera miał połączyć Prusy Wschodnie z Trzecią Rzeszą. Był to jeden 
mającej stanowić część korytarza. Problem budowy korytarza, po zdecydowanej odmowie ze strony Polski, Rosjanie podnieśli ponownie w 2001 r., próbując wymusić na Litwie - głównie w latach 2002-2004, przed wejściem tego kraju do UE - zgodę na jego przeprowadzenie przez jej terytorium. Również w tym przypadku zakończyło się to fiaskiem.

Latem 2009 roku Siergiej Bojakan, wiceprezes rosyjskiej państwowej firmy Energatom zaproponował Polsce, Litwie i Niemcom współudział w budowie elektrowni atomowej w Niemanie, $15 \mathrm{~km}$ od granicy litewskiej. Koszty budowy wynieść mają 5 mld euro. Pierwszy blok elektrowni miał powstać w 2005 roku, czyli pięć lat wcześniej niż pierwsza polska elektrownia atomowa. Jedna trzecia prądu z elektrowni miałaby pozostać w Kaliningradzie, a reszta przeznaczona byłaby na eksport. Polskie i litewskie obawy przed przystapieniem do tego projektu wynikają z możliwości zwiększenia energetycznej zależności od Rosji. Priorytetem dla obu państw była wówczas wspólna budowa nowej elektrowni atomowej na Litwie w Visaginas. Budowę Bałtyckiej Elektrowni Atomowej rozpoczęto 25 lutego 2010 roku. Będzie ona miała dwa bloki energetyczne o łącznej mocy 2300 megawat. Pierwszy blok ma być oddany do eksploatacji w 2016, drugi - w 2018 roku. Ma ona zapewnić obwodowi całkowitą niezależność energetyczną i stworzy warunki do eksportu energii elektrycznej. Polska, Litwa i Łotwa odmówiły udziału w budowie tej elektrowni. Stronie rosyjskiej nie udało się znaleźć jakiegokolwiek inwestora zagranicznego. W 2011 roku władze Litwy wniosły do rozpatrzenia przez Zgromadzenie Parlamentarne NATO sprawę budowy Bałtyckiej Elektrowni Atomowej, a także „zagrożeń związanych z tym budownictwem". W Kaliningradzie powstała inicjatywa przeciwników budowy elektrowni atomowej. W piśmie skierowanym do konsulatów generalnych m.in. Polski, Litwy, Niemiec, Szwecji i Danii mających swe siedziby na terytorium Obwodu przeciwnicy budowy tej elektrowni pisali, iż jej budowa „zagraża bezpieczeństwu ekologicznemu, w tym także państw sąsiednich, w szczególności, Litwy" ${ }^{\text {"45 }}$.

Kolejne kwestie sporne to sprawa tzw. reżimu wizowego dotyczącego ruchu tranzytowego, związana z przystąpieniem Polski do Unii Europejskiej ${ }^{46}$, w tym kwestia „drożności” na przejściach granicznych (problem tzw. „patelni”)" ${ }^{47}$, oraz współpraca

z pretekstów rozpętania II wojny światowej. Por.: E. Wojnowski, Rola Obwodu Kaliningradzkiego w strategii geopolitycznej Federacji Rosyjskiej, w: Europa a Rosja-opinie, konflikty, wspólpraca, red. Z. Anculewicz, J. Sobczak, Olsztyn 2003, s. 143-145.

${ }^{45}$ R. Zasuń, Atomowa oferta Rosji. Weźcie udziat w budowie elektrowni atomowej w obwodzie kaliningradzkim, „Gazeta Wyborcza”, 9.08.2009, s. 1; tenże, Rosja kusi atomem w Kaliningradzie, „Gazeta Wyborcza”, 8.08.2009, s. 29 oraz Atomowy interes z Rosja? Moskwa czeka na sygnat od Polski $w$ sprawie elektrowni $w$ obwodzie kalininigradzkim, ibidem z 2.03.2010, s. 23. Por. także: T. Baryła, W. Hojszyk, „Regiony i Pogranicza. Kaliningrad. Fakty. Wydarzenia. Opinie” (dalej: „R i P”) 2011, nr 2, s. 29, 43, 44.

${ }_{46}$ Por.: Polsko-rosyjska wspótpraca transgraniczna. Raport, pod red. E. Romanowskiej, B. Samojłowicz, Olsztyn 2004, s. 7-16. W maju 2009 roku władze w Moskwie zapowiedziały, iż pasażerowie promów przypływających do Kaliningradu, na których pokładzie znajdować się będą obywatele UE, będą wpuszczani na ląd bez konieczności posiadania rosyjskiej wizy. Patrz: „Das Ostpreußenblatt”, 13.06.2009, nr 24, s. 1.

47 „Patelnia”, nazywana także ,odstojnikiem”, to specjalny plac parkingowy istniejący od 1999 roku po stronie rosyjskiej na granicy z Polską. Aby przekroczyć granicę, należy „odstać na tym parkingu” 
w ramach euroregionów „Bałtyk”, „Niemen”, „Łyna-Lawa” i „Szeszupa”48 . Najnowsze „punkty zapalne” to budowa gazociągu bałtyckiego, który ma mieć odgałęzienie do Kaliningradu ${ }^{49}$ oraz groźba zainstalowania w obwodzie broni atomowej w odpowiedzi na umieszczenie baz wojsk amerykańskich ${ }^{50}$ w Polsce i instalację tarczy antyrakietowej ${ }^{51}$.

Przystąpienie Polski do NATO i UE oraz wcześniejsze i późniejsze konflikty na linii Warszawa-Moskwa wpłynęły na postrzeganie Polski przez przeciętnego Rosjanina oraz na obraz Rosjan w Polsce. Moskiewski pisarz Wiktor Jerofiejew widzi to w ten sposób: „Kim jest Polska z punktu widzenia przeciętnego Rosjanina? Żoną, która

od kilku do kilkunastu godzin (niekiedy 2-3 dni). Stosowna opłata (wziatka) w istotny sposób skraca czas oczekiwania na przekroczenie granicy. Na tym tle dochodziło do licznych spotkań służb granicznych i celnych obu krajów w celu rozwiązania tego problemu. Por. K. Lachowski, Przestepstwa celne w obrocie towarowym i osobowym z Obwodem Kaliningradzkim w latach 1997-2001, Olsztyn 2002 (maszynopis w zbiorach autora). Według szacunków rosyjskich prawie $90 \%$ ruchu przez granice związane jest z tzw. biznesem wahadłowym (po rosyjsku nazywanym ,czelnoczniki”, a po polsku „mrówki”). Około 10\% mieszkańców regionu trudni się tym procederem. Głównie jest to przewóz (większej lub mniejszej liczby papierosów) na ciele przemytników lub w bagażu podręcznym, ale także alkoholu lub benzyny. Z procederu tego żyje także wiele osób z miejscowości przygranicznych w Polsce. W 2005 r. służby celne przejęly na trzech przejściach drogowych i jednym kolejowym (Kaliningrad-Gdynia) około $180 \mathrm{mln}$ sztuk przemycanych papierosów (9 $\mathrm{mln}$ paczek), które zostały skonfiskowane. Por.: I. Trusewicz, Mrówka na urlopie. Polska-Rosja. Przejście w Bezledach, „Rzeczpospolita”, 1.01.2003, s. A6; Doba na patelni. Pogłoski o zamknięciu odstojnika na granicy rosyjsko-polskiej sq mocno przesadzone, „OK” 2006, nr 12, s. 56, 57; S. Brzozowski, Wyrok na przemytników rosyjskich papierosów. Po dwa miliony do oddania, „Gazeta Olsztyńska”, 24-25.07.2010, s. 5.

48 Por.: Polska wobec Obwodu Kaliningradzkiego, red. A. Żukowski, Olsztyn 2004. W pracy tej znajduje się obszerna bibliografia polskich publikacji na temat Obwodu Kaliningradzkiego oraz relacji polsko-kaliningradzkich w wymiarze państwowym, regionalnym i lokalnym. Por. także: A. Żukowski, Pogranicze pótnocno-wschodnie Polski a polska polityka zagraniczna. Refleksje nad perspektywq stosunków z Obwodem Kaliningradzkim, w: Polskie pogranicza a polityka zagraniczna u progu XXI wieku, red. R. Stemplowski, A. Żelazo, Warszawa 2002, s. 323-348; P. Kraszewski, Koncepcje rozwiazania tzw. problemu kaliningradzkiego po rozpadzie Zwiazku Radzieckiego, „Sprawy Wschodnie" 2003, nr 1, s. 49-63; P. Borowiec, Polska granica z Obwodem Kaliningradzkim wobec rozszerzenia Unii Europejskiej, „Rocznik Wschodni” 2003, nr 9, s. 86-102; A. Maciejewski, Przygotowania Obwodu Kaliningradzkiego do sasiedztwa z Uniq Europejska, „Polityka Wschodnia” 2002, nr 1, s. 157-164; E. Wojnowski, Die Zusammenarbeit an der Grenze zwischen Polen und dem Kaliningrader Gebiet, w: Grenzen im Ostblock und ihre Überwindung, Berlin 2001, s. 201-216; Obwód Kaliningradzki Federacji Rosyjskiej. Wybór dokumentów 1994-2004, oprac. T. Baryła, W. Hojszyk, E. Wojnowski, Olsztyn 2004; Kalendarium wspótpracy województwa warmińsko-mazurskiego z Obwodem Kaliningradzkim, Olsztyn-Elblag-Kaliningrad 2005.

49 Por.: T. Walat, Dzień w którym wyptynie ryba, „Polityka” 2006, nr 11, s. 52-55.

50 Por.: J. Topolski, Militarna pozycja Federacji Rosyjskiej, w: Federacja Rosyjska w stosunkach międzynarodowych, pod red. A. Czarnockiego, J. Topolskiego, Lublin 2006, s. 84-107; M. Szymański, Potencjat militarny w Obwodzie Kaliningradzkim a bezpieczeństwo Polski, „Przegląd Zachodni” 1999, nr 1; M. Wojciechowski, Na wasze bazy nasze rakiety, „Gazeta Wyborcza”, 12.01.2004, s. 9; F. Łukjanow, Rosjo, gdzie twój wróg, ibidem, 12.01.2004, s. 16, 17.

51 Por.: T. Bielecki, Rosjanie groża Polsce rakietami, „Gazeta Wyborcza”, 16.02.2007, s. 1, 10; W. Radziwinowicz, Rakietowa odpowiedź na tarczę, „Gazeta Wyborcza”, 5.07.2007, s. 9. Por. także: M. Chełminiak, Polska polityka zagraniczna a perspektywy rozwoju kontaktów Polski z Obwodem Kaliningradzkim Federacji Rosyjskiej, w: Polska a Obwód Kaliningradzki Federacji Rosyjskiej. Teraźniejszość i wyzwania przyszłości, red. A. Żukowski, Toruń 2008, s. 247-268, tamże obszerna charakterystyka najnowszego stanu badań w Polsce. 
porzuciła swego męża - Związek Radziecki. Odeszła do NATO, do Unii Europejskiej. Nikt nie ugania się za żonami, które ostentacyjnie zdradziły ślubnego. Dlatego polscy politycy, obrażeni na to, że mąż rogacz nadal za nimi nie biega i nie zagląda im w oczy, przypominają mi panienki, które chciałyby zachować cnotę i mieć pieniądze. Po rosyjsku brzmi to brutalniej: chciałyby i rybkę zjeść, i na ch... siąść. Realia są takie, że skoro zjedliście amerykańską rybkę, musicie się obejść bez rosyjskiego, hm, wkładu",52.

$\mathrm{Z}$ moich własnych badań terenowych prowadzonych na pograniczu polsko-kaliningradzkim wynika, iż obie społeczności nie są do siebie wrogo nastawione. Wręcz przeciwnie, można generalnie mówić o wzajemnej sympatii i zrozumieniu. Bazuje ona w znacznej mierze na obopólnym przekonaniu, iż , wszyscy mieszkamy tu od 1945 roku, wszyscy jesteśmy bardziej lub mniej ofiarami komunizmu" (Ka-3). Inny z respondentów zauważył, iż „Polacy i Rosjanie budowali swoją egzystencję na gruzach Prus Wschodnich i gdyby nie II wojna światowa, nikogo z nas by tu nie było" (Ka-7).

$\mathrm{Na}$ zakończenie tych rozważań celowe wydaje się przypomnienie tekstu „Memorandum" w sprawie Obwodu Kaliningradzkiego, skierowanego do władz Rosji i władz Obwodu Kaliningradzkiego oraz rządów Niemiec, Polski, Litwy, Białorusi, Łotwy, Estonii i Szwecji przez uczestników międzynarodowej konferencji, która odbyła się w dniach 22-23 kwietnia 1993 roku w Instytucie Zachodnim w Poznaniu. Oto jego treść:

„Naukowcy z Rosji, Kaliningradu, Litwy, Polski i Niemiec spotkali się na konferencji w Poznaniu (Polska) w dniach 22-23 kwietnia 1993 r., aby na bazie szczegółowych studiów przygotowanych przez każdą ze stron dyskutować na temat przyszłości Obwodu Kaliningradzkiego; czyniono to z perspektywy ogólnoeuropejskiej, z myślą o wspólnym interesie, polegającym na zapewnieniu stabilizacji i rozwoju całego regionu nadbałtyckiego. Kaliningrad może stać się wzorem, jeśli chodzi o multilateralne współdziałanie przy rozwiązywaniu istotnych dla polityki zagranicznej regionalnych problemów transformacyjnych w Europie. Chodzi przy tym nie tylko o uzgodnienie interesów na płaszczyźnie oficjalnej, ale przede wszystkim o współpracę między ludźmi, o wymianę idei, o przezwyciężanie uprzedzeń i resentymentów, pokonywanie barier rozwoju gospodarczego, jak również o uświadomienie elementów integrujących wspólne dziedzictwo historyczne w regionie nadbałtyckim. Wspólne wyniki obrad ujęto w następujących punktach:

1) prawnomiędzynarodowy status Obwodu Kaliningradzkiego nie podlega dyskusji. Jego status państwowoprawny w ramach Federacji Rosyjskiej jest i pozostanie wyłącznie przedmiotem porozumienia między Obwodem i Federacją Rosyjską;

2) w interesie stopniowego przybliżania państw regionu nadbałtyckiego do europejskich procesów integracyjnych niezbędne jest wzajemne otwarcie Obwodu Kaliningradzkiego oraz Wspólnot Europejskich. Jednakże może się ono dokonać tylko w ramach odpowiednich porozumień między WE i Rosją;

52 Ojcobójca. Z W. Jerofiejewem rozmawia A. Żebrowska, „Duży Format” dodatek do „Gazety Wyborczej”, 17.10.2005, s. 8. W świetle badań z 2005 roku Rosjanie okazali się dość obojętni wobec Polski - za przyjaciół uznaje nas 5\% Rosjan, za wrogów - 4\%. Kto wróg, kto przyjaciel. Poglady Rosjan ksztattuje telewizja, „Gazeta Wyborcza”, 18-19.06.2005, s. 9. Zdaniem Polaków za zły stan stosunków polsko-rosyjskich w $44 \%$ winę ponosi Rosja, tyle samo badanych uważa, że „obydwie strony w równym stopniu”, 9\% że przede wszystkim Polska. „Gazeta Wyborcza”, 28.12.2005, s. 4. 
3) zmniejszenie obecności militarnej w Obwodzie Kaliningradzkim do poziomu wystarczającego dla celów obrony (stosownie do redukcji przebiegających na obszarze nadbałtyckim) jest nieodzowną przesłanką dla rozwoju gospodarczego i społecznego na tym terenie i poza nim. Wspólne poczucie bezpieczeństwa można osiagnąć poprzez współpracę danych państw w ramach Północnoatlantyckiej Rady Współpracy;

4) istnieje duże zainteresowanie ze strony wszystkich państw sąsiednich koncepcją wolnej strefy gospodarczej na terenie Obwodu Kaliningradzkiego. Na to trzeba by stworzyć prawne i administracyjne warunki ramowe, aby rosyjscy i zagraniczni przedsiębiorcy znaleźli tam korzystny dla siebie klimat. Odpowiedzialność za przygotowanie przejrzystych i w miarę prostych wszelkich wstępnych warunków organizacyjnych, spoczywa na władzach w Moskwie i Kaliningradzie;

5) kontrproduktywne dla rozwoju wzajemnych stosunków między sąsiadami w tym regionie są, ze względu na konieczność przezwyciężania starych schematów myślowych i koncepcji porządku międzynarodowego, wszelkie projekty w rodzaju tworzenia korytarzy, kondominiów etc.;

6) koncepcja współpracy w rosyjskim Obwodzie Kaliningradzkim powinna sprzyjać współżyciu i zapewnieniu możności rozwoju różnych narodowości, wyznań, jak i grup społecznych i kulturowych. Należy do tego promocja specjalnego dla nich systemu wychowania i oświaty, jak również odpowiednia polityka mass mediów;

7) dla rozwiązywania powstających problemów zaleca się, na wzór istniejących już praktyk europejskich, intensywną współpracę przygraniczną na płaszczyźnie jednostek administracyjnych Obwodu Kaliningradzkiego, Litwy i Polski. Pokonywanie zaostrzających się problemów ekologicznych nie jest możliwe bez współpracy transgranicznej;

8) przyspieszenie procesów modernizacyjnych w tym regionie zakłada sprawne włączenie Obwodu Kaliningradzkiego do ogólnoeuropejskiego systemu transportu i komunikacji, jak również dostosowanie warunków odprawy granicznej do standardów europejskich;

9) szczególną uwagę należy poświęcić tworzeniu instytucji europejskich mających służyć popieraniu spotkań międzyludzkich i kulturalnych na terenie Obwodu. Chodzi tu przede wszystkim o rozbudowanie sieci instytucji w rodzaju Domów Europejskich (Europa-Häuser), schronisk młodzieżowych i innych miejsc spotkań;

10) Wspólnota Europejska będzie musiała w większym stopniu udzielić poparcia współpracy gospodarczej, naukowej, kulturalnej i społecznej Obwodowi w ramach istniejących już programów;

11) sygnatariusze niniejszego Memorandum proponują przygotowanie konferencji międzynarodowej z udziałem przedstawicieli rządów; deklarują też swą gotowość udostępnienia materiałów studyjnych oraz wykonania wstępnych prac koncepcyjnych" ${ }^{\text {"53- }}$.

53 Sygnatariuszami tego „Memorandum” byli: w imieniu rosyjskiej grupy badawczej: prof. dr Oleg T. Bogomołow, członek Rosyjskiej Akademii Nauk i dyrektor Instytutu Studiów Gospodarczych i Politycznych (IMEPI), Moskwa, prof. dr Wiaczesław Dasziczew, Kierownik Centrum Studiów Rosyjsko-Niemieckich w IMEPI, Moskwa; w imieniu kaliningradzkiej grupy badawczej: prof. dr Gienadij Fiedorow, Uniwersytet w Kaliningradzie; w imieniu litewskiej grupy badawczej: Justas Paleckis, doradca ds. zagranicznych prezydenta Republiki Litewskiej, Wilno, Vytautas Plackaitis, poseł Sejmu (Seimas) Republiki Litewskiej, Wilno; w imieniu polskiej grupy badawczej: prof. dr hab. 
Problem kaliningradzki pojawił się ponownie na arenie europejskiej w latach 2008-2010, kiedy to Polska zawarła umowę z USA w sprawie projektu budowy tzw. tarczy antyrakietowej w Radzikowie pod Słupskiem. Strona rosyjska zagroziła, iż zainstaluje w Obwodzie baterie rakiet Iskander ${ }^{54}$. Kolejnym problemem okazało się przybycie w maju 2010 roku do Moraga pierwszej grupy 33 amerykańskich żołnierzy z bazy w Kaiserslauten w Niemczech, którzy obsługiwać będą rotacyjnie baterię rakiet „Patriot”. Wraz z nimi przyjechało 12 samochodów ciężarowych i dodatkowy personel. Ogółem cała grupa liczyła sto osób.

Bateria rakiet składa się z 4-8 wyrzutni pocisków PAC 2 i PAC 3. Przez dwa początkowe lata Amerykanie mają przebywać w Polsce czasowo, potem na stałe ${ }^{55}$. Liczący 15 tys. mieszkańców Morąg leży około 70 km od granicy z Obwodem Kaliningradzkim i $90 \mathrm{~km}$ od Kaliningradu. Zdaniem Ministerstwa Spraw Zagranicznych Rosji nie sprzyja to umacnianiu bezpieczeństwa i rozwojowi zaufania w Europie. $Z$ tego głównie względu, tzn. by nie drażnić Rosjan, Amerykanie rozważają możliwość przeniesienia „Patriotów” do Centrum Szkolenia Artylerii i Uzbrojenia w Toruniu. W sierpniu 2011 r. w prasie rosyjskiej i polskiej pojawiły się informacje, iż w nadbałtyckiej enklawie nad granicą z Polską Moskwa zaczyna rozmieszczać dwa dywizjony najnowocześniejszych rakiet przeciwlotniczych S-400 mogących razić cele oddalone o $400 \mathrm{~km}$ od wyrzutni. Zdaniem rosyjskich generałów broń ta ma być fundamentem obrony przeciwrakietowej, bo może także niszczyć rakiety z głowicami jądrowymi. Informacje te okazały się nieprawdziwe, gdyż rakiety S-400 znajdują się dopiero w fazie prób $^{56}$.

Innym ważnym problemem o znaczeniu europejskim okazał się spór o ruch bezwizowy pomiędzy Obwodem Kaliningradzkim a Polską i Litwą. Strona polska od dłuższego czasu zabiega w Unii Europejskiej o objęcie całego Obwodu umową o małym ruchu granicznym. Obecne unijne regulacje pozwalają na ustanowienie takiego

Anna Wolff-Powęska, dyrektor Instytutu Zachodniego (IZ), Poznań, dr Tomasz Budnikowski, IZ, Poznań, doc. dr hab. Andrzej Sakson, IZ, Poznań; w imieniu niemieckiej grupy badawczej: prof. dr Heinrich Vogel, dyrektor Bundesinstitut für ostwissenschaftliche und Internationale Studien (BIOst), Kolonia, dr Olga Alexandrowa, BIOst, Kolonia, dr Dieter Bingen, BIOst, Kolonia. Por. A. Sakson, Teraźniejszość i przyszłość Obwodu Kaliningradzkiego (Królewca), „Przegląd Zachodni” 1994, nr 3, s. 200-202.

54 Por. W. Radziwinowicz, Iskandery w Kaliningradzie? Tak, ale nie teraz, „Gazeta Wyborcza”, 12.02.2009, s. 8. W kwietniu 2009 roku wiceszef rosyjskiego MSZ Siergiej Rybakow powtórzył rosyjską groźbę, że w razie powstania baz tarczy w Polsce i Czechach Rosjanie umieszczą rakiety Iskander w Obwodzie Kaliningradzkim, „Gazeta Wyborcza”, 22.04.2009, s. 14.

55 System polega na tym, że bateria przyjeżdża do Polski raz na kwartał, a po miesiącu wraca do macierzystej bazy w Niemczech. Por.: W. Sawicka, Morag czeka na Patrioty, „Gazeta Wyborcza”, 21.01.2010, s. 3; Trwa rozładunek transportu amerykańskiego, „Gazeta Olsztyńska”, 18.05.2010, s. 8; P. Pytlakowski, Garnizon Morag z Patriotami, „Polityka” 2010, nr 23, s. 108-113; J. Tschernyschew, Ein Stück Geopolitik. „Patriot”-Raketen in Mohrungen: Polen begrüßt die Stationierung, Russland zeigt sich konsterniert, „Das Ostpreußenblatt” 2010, nr 22, s. 1.

56 T. Ciechoński, Morag (chyba) żegna Patrioty. Nie chca drażnić Rosji, „Gazeta Wyborcza. Olsztyn”, 12.10.2010, s. 1; M. Podolski, US Army nie trafito w Morag, „Gazeta Wyborcza”, 24-25.09.2011, s. 5. Por. także: W. Radziwinowicz, Rosja straszy wirtualnymi rakietami, „Gazeta Wyborcza", 10.08.2011, s. 11 oraz Rosyjskie rakiety zagrażaja największym polskim miastom, http://www.wv.pl (24.09.2011). 
przepływu osób w pasie $30 \mathrm{~km}$ od granicy, lokalnie może być on poszerzony do $50 \mathrm{~km}^{57}$. Jednym z celów polskiej prezydencji w UE (lipiec-grudzień 2011 roku) jest wprowadzenie małego ruchu granicznego pomiędzy Obwodem a północno-wschodnią Polską ${ }^{58}$.

Polskie starania spotkały się jednak z niechętnym stanowiskiem rządu litewskiego. Władze w Wilnie obawiają się, że niekontrolowany ruch wizowy zagraża jej bezpieczeństwu $^{59}$.

Problematyce ruchu bezwizowego poświęcone było głównie spotkanie ministrów spraw zagranicznych Rosji, Polski i Niemiec, które odbyło się 21 maja 2011 roku w Kaliningradzie. Podczas konferencji prasowej na temat wyników rozmów minister spraw zagranicznych Federacji Rosyjskiej Siergiej Ławrow oświadczył, że umowa w sprawie małego ruchu przygranicznego między Rosją i Polską za miesiąc będzie przedłożona Parlamentowi Europejskiemu. Wskazał: „Porozumieliśmy się co do bardziej aktywnego realizowania inicjatyw dodatkowych w interesie rozwoju Obwodu Kaliningradzkiego. Szczególne miejsce wśród tych inicjatyw zajmie zadanie stworzenia ram prawnych dla „małego ruchu przygranicznego”. Rosja i Polska przygotowały stosowną umowę, która wymaga akceptacji Brukseli i jesteśmy bardzo wdzięczni Niemcom za poparcie, którego Niemcy udzielają nam w przyspieszeniu tej decyzji"

W drodze wyjątku Komisja Europejska chce włączyć cały obwód kaliningradzki w strefę przygranicznego ruchu bezwizowego oraz rozszerzyć ją także po polskiej stronie granicy.

Polski pas obejmowałby sporą części województwa pomorskiego - Sopot, Gdańsk, Gdynię oraz powiaty pucki, gdański, nowodworski i malborski, a w województwie warmińsko-mazurskim Elbląg, Olsztyn oraz powiaty elbląski, braniewski, lidzbarski, bartoszycki, olsztyński, kętrzyński, mrągowski, węgorzewski, giżycki, gołdapski i olecki. Mieszkańcy tych rejonów będą mogli w przyszłości uzyskać stałe zezwolenia, które pozwoli im na podróżowanie po strefie przygranicznej bez wizy (nie w celach zarobkowych).

Propozycję Komisji Europejskiej musi jeszcze zatwierdzić Rada UE i Parlament Europejski, z czym nie powinno być większego kłopotu. Wcześniej Litwa wycofała się

57 Por. M. Bełza, Warmia i Mazury: Czekamy na was, Rosjanie. Już bez wiz, „Gazeta Wyborcza”, 8.04.2010, s. 8 .

58 M. Wojciechowski, Przybliżmy Unii Rosję. Przed polska prezydencja w UE, „Gazeta Wyborcza", 14.10.2010, s. 21.

59 Zdaniem Auriusa Bačiulisa, komentatora tygodnika „Veidas”: „Wprowadzenie tego, co proponuje Polska, oznaczałoby niekontrolowany rosyjski tranzyt przez Litwę. Rosja już dawno domagała się tego od nas. Ale ten projekt zagraża naszemu bezpieczeństwu narodowemu. Po zniesieniu wiz nie będziemy wiedzieli ani kto przekracza granicę naszego kraju, ani ilu obywateli rosyjskich znajduje się na naszym terytorium. Za zniesieniem wiz dla Rosjan opowiadają się przeważnie kraje odległe. Sprzeciwiają się najbliżsi sąsiedzi: kraje bałtyckie, Finlandia. Do niedawna również Polska. Jednak teraz polskie władze robią wszystko, żeby przypodobać się Rosji - nawet kosztem bezpieczeństwa sąsiadów. Na to nie ma zgody". Cyt. za: R. Mickiewicz, P. Kościński, Spór o wizy dla Rosjan. Litwa nie wesprze starań Polski o objęcie matym ruchem granicznym Obwodu Kalingradzkiego, ,Rzeczpospolita", 10.08.2010, s. A8.

60 ,R i P” 2011, nr 2, s. 45. 
z zastrzeżeń wobec ujęcia Obwodu Kaliningradzkiego specjalnymi regulacjami w sprawie małego ruchu granicznego ${ }^{61}$.

Leonid Gorbienko, gubernator kaliningradzki w latach 1996-2000, stwierdził w 2009 roku, że „Obwód Kaliningradzki powinien pozostać terytorium rosyjskim. Trzeba mu tylko nadać specjalny status konstytucyjny i zmienić nazwę na Federalny Obwód Nadbałtycki, między innymi po to, by skończyć dyskusję w sprawie jego przemianowania". Po tym oświadczeniu dziennikarz Wadim Smirnow przypomniał, że „idea nadania obwodowi statusu specjalnego była popularna na początku XXI wieku i że obecnie też się do niej wraca. Już wtedy niektórzy eksperci moskiewscy chcieli widzieć obwód jako rosyjską strefę bezcłową. Innym wydawało się, że sytuację uratuje ósmy (specjalny kaliningradzki) okręg federalny ze swoim pełnomocnikiem prezydenta FR. Byli i tacy, którzy wskazywali, że trzeba przestawić produkcję obwodu i zmienić ustawodawstwo tak, by stał się on eksporterem towarów do państw UE. Byli też lokalni eksperci, którzy postulowali przekształcenie obwodu w «zagraniczne terytorium Rosji»»"

Na początku 2009 roku Jurij Siemionow, wiceprzewodniczący kaliningradzkiej Dumy obwodowej z ramienia KP FR, wystapił z inicjatywą opracowania projektu ustawy federalnej „O statusie specjalnym Obwodu Kaliningradzkiego” i skierowania tego projektu do Prezydium Dumy państwowej. Jednak zamiar ten nie uzyskał wsparcia Jednej Rosji i wówczas Siemionow wycofał wniosek i zapowiedział, że projekt sam opracuje i skieruje do Dumy państwowej za pośrednictwem Jurija Sawienki. Nie są znane dalsze losy tej inicjatywy ${ }^{63}$.

Pogłębiający się kryzys gospodarczy w 2009 roku, przejawiający się ponadprzeciętnym wzrostem kosztów utrzymania, wywołał ponownie dyskusję na temat ,wyspowego” charakteru regionu. Jeden z publicystów tak ujmował ten problem: „Jest tak - jesteśmy oderwani od «wielkiej» Rosji, ale dlaczego są tu wyższe opłaty? Jeżeli tranzyt gazu albo energii cieplnej przez terytorium Litwy jest drogi, to dlaczego te dodatkowe opłaty muszą ponosić Kaliningradczycy, a nie państwo, które zobowiązane jest do ochrony interesów swoich obywateli? Nasze kierownictwo zawsze deklaruje: «My - nie jesteśmy wyspą Rosji, my - jedna Rosja!». Wynika jednak, że to tylko słowa, a naprawdę my każdego dnia musimy pamiętać, że mieszkamy na wyspie. Za nasze położenie nie przysługuje nam żadna ulga - koszty utrzymania są u nas najwyższe w państwie" ${ }^{\prime 64}$.

W 2011 roku Siergiej Paśko, założyciel Ludowej Partii Bałtyckiej w Kaliningradzie wystapił z postulatem samodzielności obwodu. Napisał nawet konstytucję Kaliningradzkiej Republiki Bałtyckiej, wchodzącej co prawda w skład Federacji Rosyjskiej, ale jednocześnie należącej do UE i NATO. Republiki, w której - według słów S. Paśki - „kaliningradczycy czują się kaliningradczykami” ${ }^{35}$.

${ }^{61}$ T. Bielecki, Unia uchyla furtkę Kaliningradowi, „Gazeta Wyborcza”, 30-31.07.2011, s. 11.

${ }^{62}$ L. Gorbienko o obwodzie nad baltyckim, inni o specjalnym statusie obwodu, „R i P” 2009, nr 4, s. 6.

63 Ibidem.

64 W. Galias, Za czto płatim?, „Kaliningradskaja Prawda”, 18.02.2009, s. 14. Por. także: Bolsze i tuczsze, http://www.kaliningradka.ru (11.10.2010).

65 R. Cheda, Trójkąt w obwodzie, „Polityka” 2011, nr 19, s. 45. 
W tym samym roku Salomon Ginzburg, regionalny polityk opozycyjny w Kaliningradzie wysunął projekt nowego ustroju enklawy, która miałaby stać się okręgiem federalnym podporządkowanym bezpośrednio prezydentowi. Obwód Kaliningradzki uzyskałby tym samym większą autonomię ${ }^{66}$. Zdaniem gubernatora Obwodu Kaliningradzkiego Nikołaja Cukanowa: „Siłą swego położenia geograficznego Obwód Kaliningradzki w sposób naturalny wciagnnięty jest w proces współpracy międzynarodowej i dąży do wniesienia swego wkładu do procesów integracji europejskiej”. Nie widzi on tym samym potrzeby zmiany dotychczasowego statusu obwodu w strukturze Federacji Rosyjskiej $^{67}$.

\title{
STRESZCZENIE
}

Rozpad ZSRR spowodował, iż Obwód Kaliningradzki wchodzący obecnie w skład Federacji Rosyjskiej, stał się eksklawą sąsiadującą z Polską i Litwą. Po przystąpieniu obu tych państw w 2004 roku do Unii Europejskiej stał się on ,wyspą w UE”. Powoduje to m.in., że politycy z Moskwy i Kaliningradu, powołując się na argumentację geostrategiczną, regularnie składają zapewnienia o trwałej przynależności Obwodu Kaliningradzkiego do Rosji. Kwestia ta uzyskała specjalną nazwę ,problem kaliningradzki”. Wśród licznych koncepcji o charakterze geopolitycznym na czoło wysuwają się dwie: obwód jako najbardziej na zachód wysunięta wojskowa forpoczta Rosji oraz pilotażowy obszar współpracy z Unią Europejską. Pomimo, iż co pewien czas pojawiają się rozliczne koncepcje dotyczące zwiększenia samodzielności i autonomii tego obszaru, to jednak jego przynależność do Rosji nie budzi wątpliwości.

\section{GEOSTRATEGIC ASPECTS OF THE „KALININGRAD PROBLEM”}

\begin{abstract}
After the collapse of the USSR, the Kaliningrad Oblast, which currently constitutes a part of the Russian Federation, has become an exclave neighboring Poland and Lithuania. After these two countries joined the European Union in 2004 the Kaliningrad Oblast has become an 'isle in the EU'. One of the outcomes of this situation involves regular statements issued by politicians from Moscow and Kaliningrad reassuring that on account of its geostrategy the region is a permanent part of Russia. A special name has even been coined to address this matter - the Kaliningrad issue. There are two main geopolitical concepts: the region is Russia's westernmost military outpost; and a pilot region for collaboration with the European Union. Although, different concepts have emerged concerning the increased independence and autonomy of this region, its inclusion in Russia is beyond doubt.
\end{abstract}

${ }^{66}$ W. Radziwinowicz, Kaliningradzki obwód specjalny, „Gazeta Wyborcza”, 2.07.2011, s. 9.

${ }^{67}$ „R i P” 2011, nr 2, s. 44-45. 